\title{
Hydroxypyridinone and 5-Aminolaevulinic Acid Conjugates for Photodynamic Therapy
}

\author{
Sinan Battah, ${ }^{\dagger}{ }^{\S}$ Robert C. Hider, ${ }^{\ddagger}$ Alexander J. MacRobert, ${ }^{\S}$ Paul S. Dobbin, ${ }^{\dagger}$ and Tao Zhou ${ }^{*}, \|_{\odot}$ \\ ${ }^{\dagger}$ School of Biological Sciences, University of Essex, Colchester CO4 3SQ U.K. \\ ${ }^{\ddagger}$ Division of Pharmaceutical Sciences, King’s College London, 150 Stamford Street, London SE1 9NH, U.K. \\ ${ }^{\S}$ Division of Surgery and Interventional Science, University College London, Charles Bell House, 67-73 Riding House Street, London \\ W1W 7JE, U.K. \\ ${ }^{\|}$School of Food Science and Biotechnology, Zhejiang Gongshang University, Hangzhou, Zhejiang 310018, P. R. China
}

Supporting Information

ABSTRACT: Photodynamic therapy (PDT) is a promising treatment strategy for malignant and nonmalignant lesions. 5Aminolaevulinic acid (ALA) is used as a precursor of the photosensitizer, protoporphyrin IX (PpIX), in dermatology and urology. However, the effectiveness of ALA-PDT is limited by the relatively poor bioavailability of ALA and rapid conversion of PpIX to haem. The main goal of this study was to prepare and investigate a library of single conjugates designed to coadminister the bioactive agents ALA and hydroxypyridinone (HPO) iron chelators. A significant increase in intracellular PpIX levels was observed in all cell lines tested when compared to the administration of ALA alone. The higher PpIX levels observed using the conjugates correlated well with the observed phototoxicity following exposure of cells to light. Passive diffusion appears to be the main mechanism for the majority of ALA-HPOs investigated. This study demonstrates that ALA-HPOs significantly enhance phototherapeutic metabolite formation and phototoxicity.

\section{INTRODUCTION}

Photodynamic therapy (PDT) is based on the activation of exogenously applied or endogenously formed photosensitizers by visible light in the presence of molecular oxygen. Photosensitization upon light activation results in formation of singlet oxygen, which is a powerful oxidant, leading to the damage of a variety of subcellular substrates and cell death. ${ }^{1-4}$ 5-Aminolaevulinic acid photodynamic therapy (ALA-PDT) utilizes the haem biosynthesis pathway to transiently produce excess (and clinically useful) amounts of the natural endogenous photosensitizer protoporphyrin IX (PpIX). This is achieved by the addition of exogenous ALA, which enters the haem biosynthesis pathway. ${ }^{5,6}$ The main advantage of ALAPDT is the short half-life of its photosensitizing effects, which reduces the duration of skin photosensitivity and its efficacy using topical administration. ${ }^{7}$ However, several factors affect ALA-PDT and limit its clinical potential. In particular, the hydrophilic nature of ALA limits its rate of uptake into neoplastic cells and/or penetration into tissue. ${ }^{8}$ Considerable efforts have been made recently to overcome the bioavailability limitations associated with ALA, which have mainly been centered on the development of ALA prodrugs with higher lipophilicity, such as esters ${ }^{7,9-15}$ and peptide derivatives. ${ }^{16-18}$ In simple ester conjugates, ALA is cleaved at the C-terminus via interaction with esterases, but in some ALA conjugates cleavage

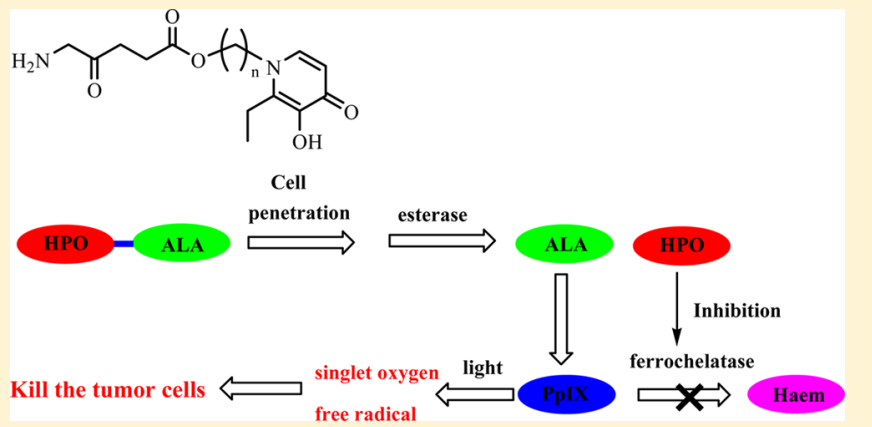

at the $\mathrm{N}$-terminus is also required via peptidases ${ }^{15,16}$ and phosphatases. ${ }^{14}$ The methyl and hexyl esters of ALA have been approved for topical treatment of basal cell carcinoma in both Europe and Australia. The use of different delivery vehicles, such as microspheres, liposomes, conjugate antibodies, has also been investigated. ${ }^{19}$

The stage following PpIX production in the haem pathway is the insertion of ferrous iron $\left(\mathrm{Fe}^{2+}\right)$ under the action of the ferrochelatase to convert PpIX into haem. ${ }^{6}$ The presence of free haem acts as a negative feedback mechanism inhibiting ALA synthesis. ${ }^{6}$ The exogenous administration of large amounts of ALA bypasses this negative feedback signal. ${ }^{20}$ The resultant accumulation of PpIX within the cells is the rate-limiting step for conversion of PpIX to haem by ferrochelatase. ${ }^{11,21,22}$ An additional approach to achieve a greater PpIX accumulation involves the chelation of intracellular iron. As a result, the conversion of PpIX to haem is decreased, further enhancing the accumulation of PpIX in the cell. ${ }^{7,8,22}$ The nonspecific membrane-impermeable metal chelator ethylenediamine tetraacetic acid (EDTA) has been shown to moderately increase PpIX levels in epithelial skin tumors in combination with ALA. ${ }^{23,24}$ Desferrioxamine (DFO) is more effective than EDTA

Received: March 6, 2017

Published: March 31, 2017 
at elevating PpIX in cells due to its greater affinity for iron than EDTA. ${ }^{25-27}$

In our studies using 3-hydroxypyridin-4-one chelators (HPO), a combination of ALA and 1,2-diethyl-3-hydroxypyridin-4-one (CP94, 26) in PDT proved to be an effective technique to increase the efficacy of ALA-PDT within cells in vitro and in vivo. ${ }^{28-31}$ The concept of exploiting high affinity iron(III) chelators for ferrochelatase inhibition in order to increase the ALA-induced PpIX levels is based upon the ability of these compounds to stimulate the oxidation of $\mathrm{Fe}^{2+}$ to $\mathrm{Fe}^{3+}$ at low concentration, with $\mathrm{O}_{2}$ acting as the oxidant. Compound 26 is a member of the hydroxypyridinone family of bidentate iron chelators. It is particularly effective at chelating intracellular iron due to its lower molecular weight and higher lipophilicity than either DFO or EDTA. ${ }^{32-35}$ However, coadministration of ALA and iron chelator would be limited by the differing pharmacological properties of the two agents. In contrast, the molecules in which ALA and HPO agents are coupled via cleavable linkages would release the two agents following cellular uptake. The enhanced porphyrin levels would therefore arise principally from simultaneous delivery of the synergistically acting bioactive agents to cell. Indeed, in our previous work, it has also been demonstrated that some ALA/HPO conjugates are more efficient than ALA and ALA in combination with HPO for PpIX production in some tumor cell lines. $^{36,37}$

Because HPOs, such as $\mathbf{2 6}$, are more effective at chelating intracellular iron than desferrioxamine due to the superior cell membrane permeability of HPOs, ${ }^{38}$ in the present work, a range of ALA-HPO conjugates were designed and synthesized in order to synergistically promote intracellular phototoxicity. There is compelling evidence with regards to the important role of the conjugation bonding, the spacers/linkers types, and length of the spacers for ALA-PDT based on the literature and our previous work. ${ }^{7,9-13,16,17,36,37}$ For example, Battah et al. found that increasing the linker length in ALA dendritic derivatives led to an enhancement of intracellular porphyrin generation, which was ascribed to a reduction in steric hindrance to esterase access. ${ }^{13}$ However, linkers can also affect the lipophilicity of the conjugate, which will in turn affect its bioavailability. $^{13}$

The goal of this investigation was to optimize and determine the efficacy of several spacers that control the PDT of ALAHPO conjugates. The chosen iron chelators have similar chemical structures to that of 2-ethyl-3-hydroxypyridin-4-one (26) attached to ALA via a variety of links (Chart 1 ). The two moieties were covalently bonded through ester bonds, which were predicted to hydrolyze enzymatically under intracellular conditions. The efficacy of these ALA-HPO conjugates has been investigated in various cell lines and the kinetics of PpIX fluorescence and phototoxicity monitored.

\section{RESULTS AND DISCUSSION}

2.1. Chemistry. The ability of ALA-HPO conjugates to penetrate the tumor cell membrane and ease of liberating free ALA molecule intracellularly are important factors affecting the activity of the prodrugs. To obtain ALA prodrugs with high PpIX generation efficiency and high phototoxicity against tumor cells, a range of ALA-HPO conjugates were designed: (a) HPO has a similar structure to 26 , features a ethyl group at position 2, and is linked to ALA through different lengths of hydrocarbon spacers $\left.\left(\mathrm{CH}_{2}\right)_{n}, n=2-12\right)$ in compounds $(7 \mathbf{a}-$ 7f) via readily cleavable ester bond; (b) the same HPO with
Chart 1. Structures of ALA-HPO Conjugates and ALA Esters<smiles>CCc1c(O)c(=O)ccn1CCCCCCC(=O)OCCC(=O)CN</smiles>

ALA-HPO 7

$7 \mathbf{a}: \mathrm{n}=2 ; 7 \mathbf{b}: \mathrm{n}=4 ; \mathbf{7 c}: \mathrm{n}=6$;

$7 \mathbf{d}: \mathrm{n}=8 ; 7 \mathrm{e}: \mathrm{n}=10 ; \mathbf{7 f}: \mathrm{n}=12$<smiles>CN(C)c1c(O)c(=O)ccn1CC(=O)OCCC(=O)CCN</smiles><smiles>CCc1c(O)c(=O)ccn1CCOC(C)(C)COCC(C)OC(=O)CCC(=O)CN</smiles><smiles>CCCCCCOC(=O)CCC(=O)CN</smiles>

hexyl ALA (24)<smiles>CCCCCCCCOC(=O)CCC(=O)CN</smiles>

octyl ALA (25) ethyl group at position 2 is linked to ALA through a triethylene glycol spacer in compound (23); (c) the ethyl group of HPO at position 2 was substituted with 1-hydroxylethyl in compound (12) and a methylamino carbonyl group in compound (18), and both groups were linked to ALA via ester bonds in these two compounds with a $\left(\mathrm{CH}_{2}\right)_{6}$ hydrocarbon chain; (d) hexylALA and octyl-ALA were chosen for comparison (compounds 24 and 25), respectively (Chart 1).

Preparation of ALA-HPO Conjugates 7. The synthetic route of ALA-HPO conjugates 7 starting from ethyl maltol (1a) is outlined in Scheme 1. The benzylation of ethyl maltol

\section{Scheme 1. Synthesis of ALA-HPO Conjugates $7^{a}$}
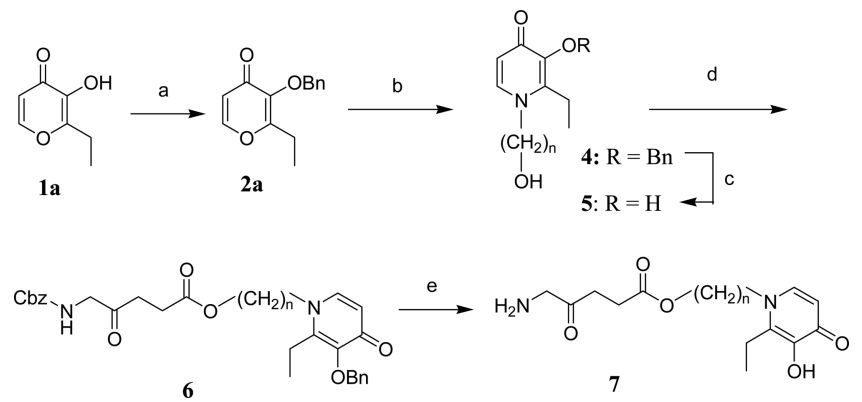

a (a) BnCl; (b) $\mathrm{NH}_{2}\left(\mathrm{CH}_{2}\right)_{n} \mathrm{OH}$ (3); (c) $\mathrm{H}_{2}, \mathrm{Pd} / \mathrm{C}, \mathrm{MeOH}$; (d) $\mathrm{N}$ Cbz-ALA (7), DCC, DMAP; (e) $\mathrm{H}_{2}, \mathrm{Pd} / \mathrm{C}$, EtOAc/MeOH.

with benzyl chloride provided $2 \mathrm{a}$ in $66 \%$ yield. The amino alcohol spacers $3 \mathbf{a}, 3 \mathbf{b}$, and $3 \mathbf{c}(n=2,4$ and 6 , respectively) are commercially available, whereas $3 \mathbf{d}, 3 \mathbf{e}$, and $3 \mathbf{f}(n=8,10$ and 12, respectively) were synthesized by the Mitsunobu reaction using triphenylphosphine $\left(\mathrm{Ph}_{3} \mathrm{P}\right)$, phthalimide, and diisopropyl azodicarboxylate (DIPAD), followed by hydrazination. Condensation of $\mathbf{2 a}$ and amino alcohol $\mathbf{3}$ under alkaline condition provided the 2-alkyl-substituted 3-hydroxypyridin-4-ones (4). 
The protected pyridinones 4 were coupled with $\mathrm{N}-\mathrm{Cbz}$ ALA, which was prepared in aqueous solution at $\mathrm{pH} \mathrm{8-10}$ at room temperature in reasonable yield, forming an ester link using the standard coupling agents 1,3-dicyclohexylcabodiimide (DCC) and 4-dimethylaminopyridine (DMAP), yielding the protected ALA-HPO conjugates 6. Deprotection of 6 was achieved by hydrogenation at $40 \mathrm{psi} \mathrm{H}_{2}$ atmosphere in methanol and ethyl acetate (1:3, by volume) in the presence of benzyl chloride to afford the hydrochlorides of ALA-HPO conjugates 7. The clogP values of this series $7 \mathbf{a}-7 \mathbf{f}$ range from -1.96 to 0.91 (Table 1).

Table 1. ClogP and $\mathrm{LD}_{50}$ Values of ALA, ALA-HPO Conjugates, and ALA Esters ${ }^{a}$

\begin{tabular}{ccccc} 
& \multicolumn{3}{c}{$\mathrm{LD}_{50}(\mu \mathrm{M})$} & \\
\cline { 2 - 4 } compd & $\mathrm{KB}$ & $\mathrm{MCF}-7$ & MCF-7R & ClogP \\
\cline { 2 - 4 } ALA & $124.0 \pm 5.2$ & $131.2 \pm 7.4$ & $122.5 \pm 8.2$ & -1.3 \\
$7 \mathbf{a}$ & $114.6 \pm 3.6$ & $124.2 \pm 5.3$ & $122.4 \pm 5.6$ & -1.96 \\
$7 \mathbf{b}$ & $65.1 \pm 6.3$ & $76.5 \pm 7.1$ & $61.2 \pm 3.9$ & -1.42 \\
$7 \mathbf{c}$ & $5.2 \pm 2.5$ & $13.4 \pm 2.6$ & $8.1 \pm 4.6$ & -0.41 \\
$7 \mathbf{d}$ & $3.1 \pm 1.1$ & $10.9 \pm 3.2$ & $4.2 \pm 2.2$ & 0.60 \\
$7 \mathbf{7}$ & $2.3 \pm 0.5$ & $8.1 \pm 4.1$ & $3.9 \pm 2.4$ & 0.73 \\
$7 \mathbf{f}$ & $2.5 \pm 0.32$ & $12.9 \pm 2.6$ & $5.5 \pm 3.1$ & 0.91 \\
$\mathbf{1 2}$ & $24.1 \pm 1.42$ & $16.6 \pm 4.4$ & $8.4 \pm 2.4$ & -1.28 \\
$\mathbf{1 8}$ & $107.5 \pm 4.6$ & $113.3 \pm 6.5$ & $104.5 \pm 5.1$ & -1.65 \\
$\mathbf{2 3}$ & $19.6 \pm 1.4$ & $15.8 \pm 5.1$ & $11.3 \pm 3.8$ & -2.37 \\
$\mathbf{2 4}$ & $2.6 \pm 0.26$ & $9.3 \pm 0.07$ & $8.4 \pm 0.12$ & 0.83 \\
$\mathbf{2 5}$ & $\mathrm{ND}$ & $\mathrm{ND}$ & $\mathrm{ND}$ & 1.84
\end{tabular}

${ }^{a} \mathrm{ClogP}$ values were obtained using an Internet software (http://www. molinspiration.com/cgi-bin/properties). $\mathrm{LD}_{50}$ values were calculated from two sets of phototoxicity experiments in KB, MCF-7, and MCF$7 \mathrm{R}$ cell lines after $4 \mathrm{~h}$ incubation using concentrations between 20 and $100 \mu \mathrm{M}$ for (ALA, $7 \mathrm{a}, 7 \mathbf{b}, \mathbf{1 2}$, and 23 ) and concentrations between 2 and $10 \mu \mathrm{M}$ for $(7 \mathrm{c}, 7 \mathrm{~d}, 7 \mathrm{e}$, and $7 \mathrm{f})$ prodrugs and irradiated with $2.5 \mathrm{~J} /$ $\mathrm{cm}^{2}$.

Preparation of ALA-HPO Conjugates 12 and 18. The synthetic route of ALA-HPO conjugate $\mathbf{1 2}$ is presented in Scheme 2. Conversion of the 2-ethyl group of $\mathbf{2 a}$ to 2 hydroxyethyl was accomplished using selenium oxide as a oxidizing agent in phenyl bromide with reflux, providing compound 8 in $43 \%$ yield; at the same time, another oxidized product 2-acetyl-3-(benzyloxy)-4H-pyran-4-one was detected (11\% yield). The newly formed hydroxyl group in compound 8

Scheme 2. Synthesis of ALA-HPO Conjugate $12^{a}$
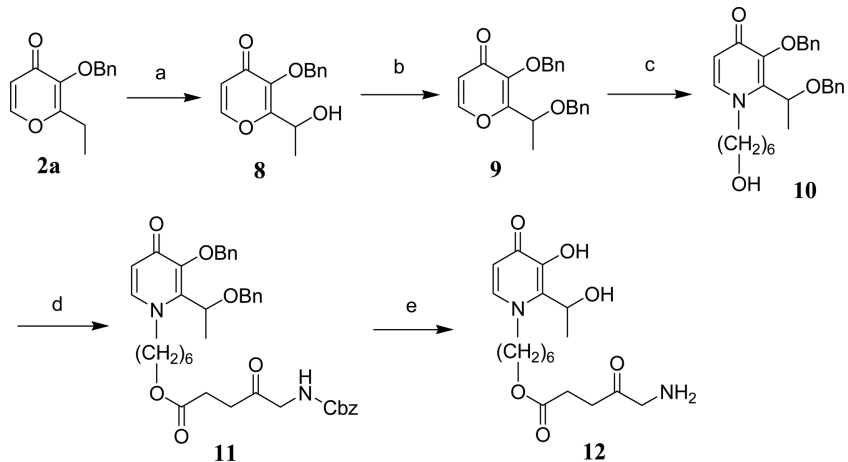

${ }^{a}$ (a) $\mathrm{SeO}_{2}$; (b) $\mathrm{BnBr}$; (c) $\mathrm{NH}_{2}\left(\mathrm{CH}_{2}\right)_{6} \mathrm{OH}$; (d) N-Cbz-ALA (7), DCC, DMAP; (e) $\mathrm{H}_{2}, \mathrm{Pd} / \mathrm{C}$. was subsequently protected using benzyl bromide in a twophase reaction using tetrabutylammonium sulfate as phase transfer catalyst, yielding 9 in $62 \%$ yield. Compound 9 was converted to the pyridinone 10 via condensation with 6-aminohexan-1-ol. Conversion of $\mathbf{1 0}$ to $\mathbf{1 2}$ was achieved using the similar procedures to that for ALA-HPO conjugates 7 (Scheme 2). The synthesis of ALA-HPO conjugate 18 using maltol (1b) as a starting material is shown in Scheme 3. The

Scheme 3. Synthesis of ALA-HPO Conjugate $18^{a}$

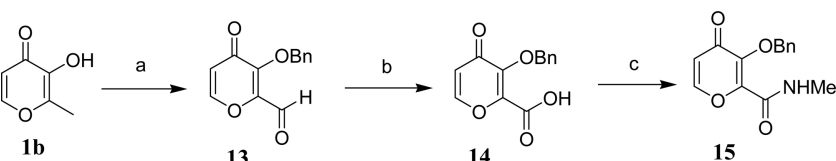

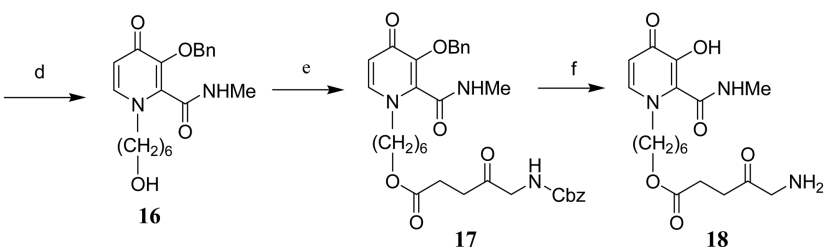

a (a) (i) $\mathrm{BnCl}$, (ii) $\mathrm{SeO}_{2}$; (b) $\mathrm{NH}_{2} \mathrm{SO}_{3} \mathrm{H}, \mathrm{NaClO}_{2}$; (c) (i) DCC, NHS, (ii) $\mathrm{MeNH}_{2}$; (d) $\mathrm{NH}_{2}\left(\mathrm{CH}_{2}\right)_{6} \mathrm{OH}$; (e) N-Cbz-ALA (7), DCC, DMAP; (f) $\mathrm{H}_{2}, \mathrm{Pd} / \mathrm{C}$.

methyl group in benzyl protected maltol was selectively oxidized by selenium oxide to form an aldehyde 13, which was further oxidized to a carboxylic acid $\mathbf{1 4}$ in the presence of sodium hypochlorite and sulfamic acid. ${ }^{39}$ The carboxyl group was activated by DCC/N-hydroxysuccimide (NHS) to form an activated ester, which was subsequently coupled to methylamine, providing a pyranone derivative 15 . Insertion of the amino alcohol spacers into the pyranone ring was achieved by refluxing the corresponding spacer with $\mathbf{1 5}$ in an alcoholic solution of sodium hydroxide at $\mathrm{pH} 12$ to afford the pyridinone 16 , which was coupled to $N-\mathrm{Cbz}$ ALA, providing 17 , the latter was subjected to hydrogenation, generating the ALA-HPO conjugate 18 (Scheme 3). The two conjugates 12 and 18 are relatively hydrophilic, the clogP values being -1.28 and -1.65 , respectively (Table 1 ).

Preparation of the Triethylene Glycol-Linked ALA-HPO Conjugate 23. The amino alcohol 20 was prepared from triethylene glycol using the Mitsunobu reaction (Scheme 4).

Scheme 4. Synthesis of ALA-HPO Conjugate $23^{a}$<smiles>C[13CH](C)OCCN1C(=O)c2ccccc2C1=O</smiles><smiles>CCc1c(OCc2ccccc2)c(=O)ccn1CCOC(C)(C)COC(C)C</smiles><smiles>CCc1c(O)c(=O)ccn1CCOC(C)(C)COC(=O)CCC(=O)CCN</smiles>

a (a) $\mathrm{HO}\left(\mathrm{CH}_{2} \mathrm{CH}_{2} \mathrm{O}\right)_{3} \mathrm{H}, \mathrm{Ph}_{3} \mathrm{P}, \mathrm{DIPAD}$ (b) $\mathrm{NH}_{2} \mathrm{NH}_{2}$; (c) 2a; (d) NCbz-ALA (7), DCC, DMAP; (e) $\mathrm{H}_{2}, \mathrm{Pd} / \mathrm{C}$. 
Condensation of $\mathbf{2 0}$ with the benzyl protected ethyl maltol (2a) yielded the derivative 21. Conjugation with protected ALA using similar methods to that described for the hydrocarbon linked molecule (4) yielded the desired ester (22), which upon hydrogenation yielded the ALA-HPO conjugate (23) (Scheme 4). This is the most hydrophilic compound of the series with a clogP value of -2.37 (Table 1).

2.2. Biological Evaluation. MCF-7 cells (human breast adenocarcinoma) and MCF-7R cells (doxorubicin resistant subline, MCF-7/DXR) were chosen to assess the efficacy of the newly synthesized ALA-HPO conjugates to generate the photoactive, fluorescent photosensitizer PpIX. PDT has been proposed in several studies as an alternative in overcoming multidrug resistance (MDR) phenotype. ${ }^{10,40}$

Therefore, the goal was to compare the accumulation and photosensitization of PpIX in MCF-7 human breast adenocarcinoma cells and its doxorubicin MDR resistant counterpart, which is characterized by the overexpression of P-gp. Human $\mathrm{KB}$ cells were also selected, which are derived from an oral epidermal squamous cell carcinoma of the mouth. ALA has been used for head and neck cancer, both topically and with oral administration. ${ }^{41,42}$

2.2.1. Concentration Dependence Profile. The fluorescence intensity of PpIX generated in MCF-7R cells after exposure of ALA or HPO-ALA conjugates for $6 \mathrm{~h}$ is presented in Figure 1.

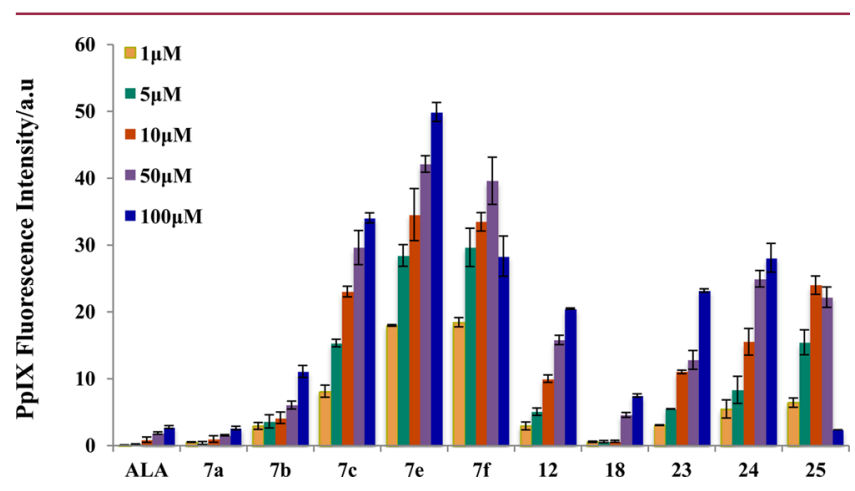

Figure 1. PpIX fluorescence intensity recorded in the MCF-7R cell line after exposure to different concentrations of ALA or ALA-HPOs or hexyl and octyl ALA ester prodrugs. The results were obtained after $6 \mathrm{~h}$ incubation at $37^{\circ} \mathrm{C}$.

Fluorescence spectra were consistent with the production of PpIX, and the peak emission at $635 \mathrm{~nm}$ was recorded for each compound. The protophyrin PpIX fluorescence induced by exposure to the majority of ALA-HPO conjugates indicated an efficient internalization and metabolism within all the investigated cell lines. PpIX production exhibited a dose dependent response for all ALA-HPO single conjugates. Porphyrin generation was enhanced over a range of concentrations between $(1-100 \mu \mathrm{M})$ after $6 \mathrm{~h}$ incubation for the compounds with long hydrocarbon spacers between ALA and HPO with the ethyl group at position 2 (Figure 1). PpIX generation was elevated significantly from $7 \mathbf{b}(n=4 \operatorname{clog} \mathrm{P}$ $-1.42)$ to $7 \mathrm{f}(n=12, \operatorname{cog} \mathrm{P} 0.91)$ by a factor of about $2-25$, reaching the maximum level with compound $7 \mathbf{e}(n=10)$, while compound 7a failed to increase PpIX greatly as compared to that produced with ALA itself at the highest concentration (100 $\mu \mathrm{M})$. This effect is attributed to the graduation of lipophilicity and the changes in steric hindrance around the ester hydrolysis sites. ${ }^{12}$ The presence of the HPO moiety within the conjugates enhanced the fluorescence intensities for $7 c, 7 d$, and $7 e$ compounds when compared with those of compounds 24 and 25, having same esters (hexyl and octyl ALA esters). ${ }^{43}$ The ALA-HPO featuring the triethylene glycol spacer 23 with a clogP value of -2.37 elevated PpIX production levels to over 20 -fold higher than ALA at $100 \mu \mathrm{M}$. PpIX accumulation induced by HPOs with the side chain, 2-ethyl (compound 7c), was superior to those HPOs with the modified side groups (hydroxyethyl and amido $-\mathrm{CONHCH}_{3}$ ) of compounds 12 and 18, respectively. Although compounds 7c, 12, and 18 were linked to ALA via the same spacers $\left(\mathrm{CH}_{2}\right)_{6}$, compound $7 \mathrm{c}$ produced PpIX fluorescence $>15$-fold that of ALA, compound 12 yielded $>10$-fold, while compound 18 failed to enhance the level of PpIX production with respect to PpIX-ALA.

2.2.2. Fluorescence Kinetics. ALA-HPOs single conjugates were clearly more efficient than ALA with respect to PpIX generation over an incubation period up to $24 \mathrm{~h}$ in $\mathrm{KB}$ cell lines (Figure 2). PpIX fluorescence kinetics of ALA-HPOs with long hydrocarbon spacers, $(\mathbf{7 d}, \mathbf{7 e}$, and $7 \mathbf{f})$ continued to exhibit significant enhancement in PpIX generation over time.

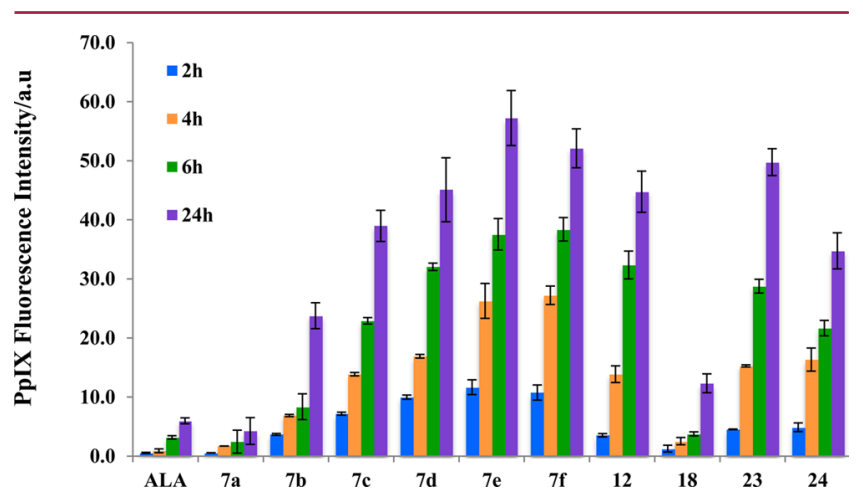

Figure 2. PpIX fluorescence time course in $\mathrm{KB}$ cell line after exposure to ALA $(50 \mu \mathrm{M})$ or ALA-HPO prodrugs $(50 \mu \mathrm{M})$. Cells were incubated at $37{ }^{\circ} \mathrm{C}$ in a $\mathrm{CO}_{2}$ humidified incubator.

The compounds with longer hydrocarbon spacers demonstrated efficient PpIX production, which was further enhanced by the presence of HPO (with a similar structure to 26) over incubation time ranging between 2 and $24 \mathrm{~h}$ (Figure 2). The existence of HPO at the other end of the spacers $(n=6, n=8$, $n=10$ ) probably led to a reduction of the toxicity of the spacers on ester formation with ALA. On the other hand, HPO could boost the penetration of conjugates through the cell membrane. ALA esters with hydrocarbons over $n=6$ have reduced bioavailabilities as a result of being trapped within bilayers. ${ }^{11,12,44}$ There have been many reports detailing the mechanistic uptake of ALA and ALA esters, which showed that the mechanism of uptake of ALA is via active transport and its esters adopt a passive diffusion pathway. ${ }^{7,9-12}$

We have compared the production of PpIX in the $\mathrm{KB}$ cell line at $37{ }^{\circ} \mathrm{C}$ and $4{ }^{\circ} \mathrm{C}$ to investigate whether ALA and ALAHPOs are transported into the cell primarily by active and passive transport mechanisms, respectively. An active transport system would be significantly inhibited by lowering the temperature to $4{ }^{\circ} \mathrm{C}$, whereas involvement of passive transport would still enable uptake at lower temperatures. The results presented in Figure 3 show that incorporation of ALA and ALA-HPOs into KB cells is temperature dependent: i.e,. when ALA-HPOs uptake was measured at $4{ }^{\circ} \mathrm{C}$, a marginal reduction of PpIX fluorescence was observed, up to $\approx 5 \%$ for most of ALA-HPOs, except PpIX generated by 12, which 


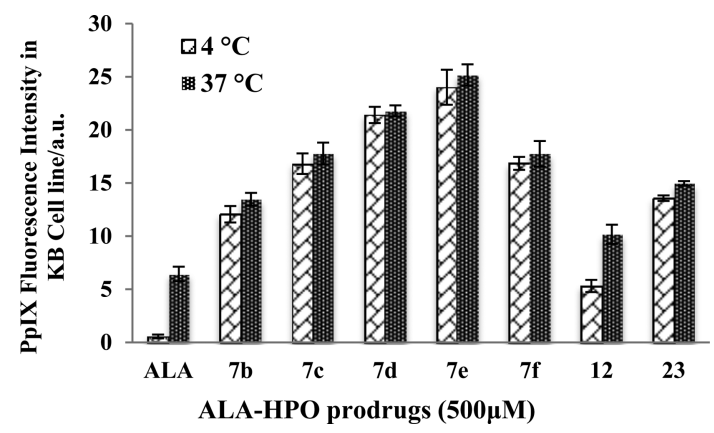

Figure 3. $\mathrm{PpIX}$ fluorescence produced by ALA or ALA-HPO prodrugs $(500 \mu \mathrm{M}), \mathrm{KB}$ cells preincubated at $4{ }^{\circ} \mathrm{C} / 1 \mathrm{~h}$, and cells incubated only at $37{ }^{\circ} \mathrm{C} / 1 \mathrm{~h}$, then both were further incubated at 37 ${ }^{\circ} \mathrm{C}$ for $4 \mathrm{~h}$, humidified with $5 \% \mathrm{CO}_{2}$.

impaired by ca. $\approx 50 \%$. In contrast, PpIX fluorescence produced by ALA was found to be significantly reduced up to $90 \%$, which is in good agreement with previous studies. ${ }^{45}$ Thus, we can conclude that an incorporation of ALA and ALA-HPOs into the KB cells (and by extrapolation the MCF-7 and MCF7R cell lines also) involves two different mechanistic pathways, with passive diffusion predominating as the main pathway for ALAHPOs single conjugates.

A comparison of PpIX fluorescence kinetics produced upon a $24 \mathrm{~h}$ time-course treatment of compounds $7 \mathrm{c}, 12$, and 18 highlighted the significant role of the HPO in PpIX production (each compound contained a hexyl linker to ALA but different structures of HPO). Compound 12 exhibited higher porphyrin fluorescence levels than 7c, while compound 18 was not effective at enhancing PpIX accumulation. Surprisingly, the hydrophilic conjugate 23 , with a triethylenglycol spacer, was found to be highly effective in all cell lines, particularly at longer time points (Figures 1, 2, and 4).

For compounds 7 , there is a clear relationship between the length of the hydrocarbon linkers and PpIX accumulation (Figures 1, 2 and 4), the effect increasing over the range $n=2$ to $n=10$, whereas with $n=12$ a relative decline was found in PpIX accumulation, probably due to the relatively low solubility of this compound. The optimum compound (7e) has a clogP value of 0.73 . The compounds $7 \mathbf{d}, 7 \mathbf{7}, 7 \mathbf{f}$, and 23 are all more effective than the hexyl- and octyl esters of ALA (24 and 25) (Figure 1).

The length of the hydrocarbon link is also directly correlated with the clogP values, and in view of their molecular size and range of clogP values, it is most probable that they gain access to the cytoplasm of cells by nonfacilitated diffusion. ${ }^{12}$ However, the high efficiency of $23(\log \mathrm{P}=-2.37)$ would indicate that this molecule is a substrate for transport, a possibility which is currently under investigation.

Although coadministration of ALA and HPOs separately (ie without conjugation) was found to enhance PpIX levels when compared to ALA alone, the additive effect was significantly weaker than when the related conjugates were investigated as shown in Figure 4. This corresponds well with our previous studies in cells using coincubation of ALA and $26 .{ }^{27}$ The use of 26 in combination with ALA and methyl ALA ester also produced significant enhancements of PpIX fluorescence in human glioma cells. At the highest concentrations of each prodrug, 26 enhanced PpIX fluorescence significantly at $3 \mathrm{~h}$ for ALA and by more than $50 \%$ at $6 \mathrm{~h}$ for ALA methyl ester. In our study, an increase in PpIX levels by approximately a factor of 2 was observed in both MCF-7 and MCF-7R cell lines in the
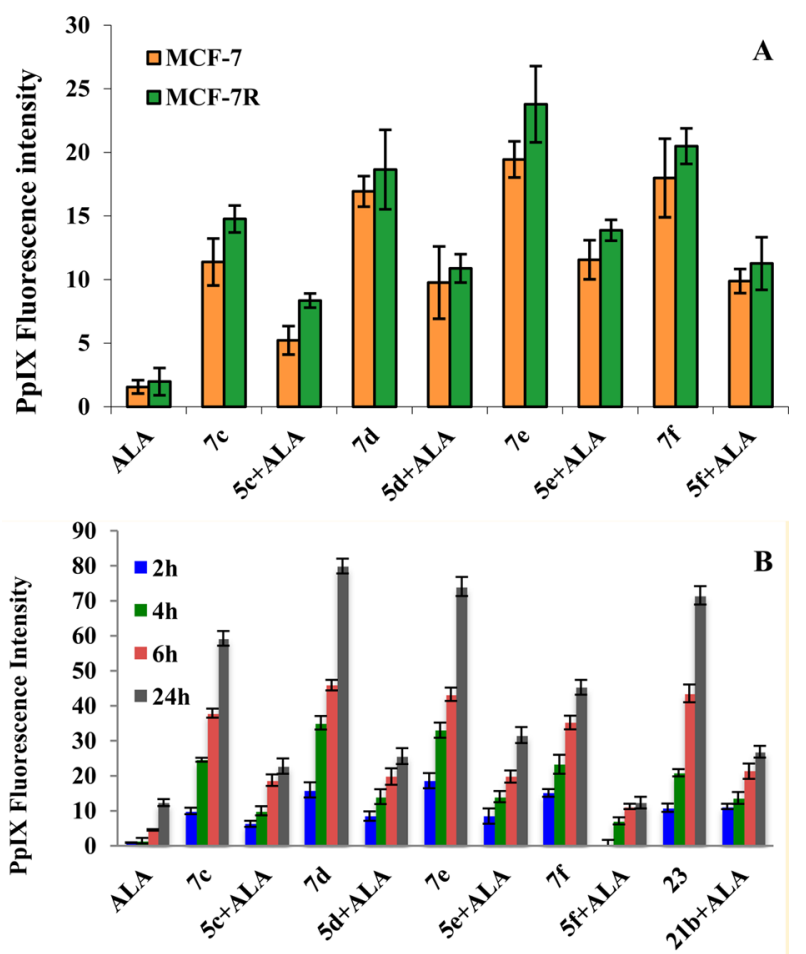

Figure 4. (A) PpIX fluorescence production recorded in MCF-7 and MCF-7R cell lines after exposure to different ALA-HPOs $(50 \mu \mathrm{M})$ in comparison to PpIX fluorescence produced by incubation of $50 \mu \mathrm{M}$ ALA and HPOs as a 1:1 mixture. The results were obtained after $6 \mathrm{~h}$ incubation at $37{ }^{\circ} \mathrm{C}$. (B) Time-course profile of PpIX fluorescence production recorded in $\mathrm{KB}$ cells after exposure to $100 \mu \mathrm{M}$ ALA, ALAHPOs conjugates, or (ALA + HPO) mixture incubated at $37{ }^{\circ} \mathrm{C}$. 5c: 2 ethyl-3-hydroxy-1-(6-hydroxyhexyl)pyridin-4(1H)-one. 5d: 2-ethyl-3hydroxy-1-(8-hydroxyoctyl)pyridin-4(1H)-one. 5e: 2-ethyl-3-hydroxy1-(10-hydroxydecyl)pyridin-4(1H)-one. 5f: 2-ethyl-3-hydroxy-1-(12hydroxydodecyl)pyridin-4(1H)-one. 21b: 1-(2-(2-(2-hydroxyethoxy)ethoxy)ethyl)-2-ethyl-3-hydroxypyridin-4(1H)-one.

presence of the conjugates when compared to the equivalent separate additions after $6 \mathrm{~h}$ incubation (Figure 4A). The synergistic effect on PpIX enhancement was also confirmed in $\mathrm{KB}$ cells over a $24 \mathrm{~h}$ time course study, employing ALA-HPO conjugates compared to coadministered ALA and HPOs. There were 2-3-fold increases in PpIX production as a result of ALA-HPO conjugate incubation over the coadministered ALA and HPOs as a mixture, particularly at the longer incubation times of 6 and $24 \mathrm{~h}$ (Figure 4B).

ALA-HPO conjugates developed in the present investigation were found to be more effective in PpIX production than our previously reported compounds, in which ALA moiety was coupled to HPO moiety via an amide linkage. ${ }^{37}$ For instance, after incubation with $\mathrm{KB}$ cells for $24 \mathrm{~h}$, conjugates $7 \mathrm{~d}$, 7e, and 7f $(50 \mu \mathrm{M})$ could produce PpIX level with 8-, 10.2-, and 9.2-fold higher than ALA, whereas the best compound in the previous study could only generate 2.9-fold higher porphyrin levels than ALA. ${ }^{37}$ This is probably due to the fact that esterase activity in cells is relatively high, thus rapidly generating free ALA and HPO while peptidase activity in cells is at a relatively lower level. The relative solubility of the compounds in the cell culture medium with the ester linkage was much higher than with the amide linkage, which may also have adversely affected the efficiency of the amide compounds. 
Uehlinger et al. investigated ALA and a range of ALA esters (methyl, ethyl, butyl, hexyl, octyl, and cyclo-hexyl esters) for the efficacy in producing PpIX in some tumor cell lines (A549, T24, J82, and BEAS-2B cells) and found that in most cell lines ALA hexyl ester showed the most efficient PpIX formation. ${ }^{11}$ $\mathrm{Wu}$ et al. also demonstrates that the cellular PpIX content in 1 mM ALA incubated nasopharyngeal carcinoma (NPC) cells is similar to that in $0.03 \mathrm{mM}$ ALA hexyl ester incubated cells, reflecting that ALA hexyl ester is more efficient than ALA for inducing PpIX production. ${ }^{41}$ However, in the present study, compounds $7 \mathrm{c}, 7 \mathrm{~d}, 7 \mathrm{e}$, and $\mathbf{7 f}$ were demonstrated to be even more efficient in PpIX formation than the ALA hexyl ester (24) (Figure 1).

Intracellular PpIX fluorescence of PAM212 keratinocyte cells has been reported to be enhanced by a factor of 5 after $6 \mathrm{~h}$ incubation with $0.01 \mathrm{mM}$ of an ALA-peptide conjugate, Ac-LPhe-ALA-OMe, compared with ALA at the same concentration, where the amino acid is conjugated at the $\mathrm{N}$-terminus of ALA. ${ }^{16}$ More extensive investigation of peptide prodrugs of ALA (Ac-Xaa-ALA-OR, where Xaa is an $\alpha$-amino acid) indicated that some of the peptide prodrugs are more efficient in inducing PpIX accumulation than ALA in PAM212 and also A549 and Caco-2 cell lines. ${ }^{17}$ For instance, at $0.1 \mathrm{mM}$, after incubation with PAM212 keratinocyte cells for $6 \mathrm{~h}$, peptide prodrugs Ac-L-Leu-ALA-OMe, Ac-L-Phe-ALA-OMe, Ac-LGluOBu- ${ }^{\mathrm{t}}$-ALA-OMe and Ac-L-Phe-Met-OMe could produce PpIX level with 7.5-, 4.4-, 6.5-, and 5.9-fold higher than ALA. ${ }^{17}$

Recently, Babič et al. have reported that two ALA hexyl ester analogues, P-ALA-Hex and PSI-ALA-Hex, which were obtained by modification of the $N$-terminus amino group, displayed reduced acute toxicity compared to the ALA hexyl ester with superior dose response profiles of protoporphyrin IX synthesis and fluorescence intensity in human glioblastoma cells in vitro. ${ }^{14}$

2.2.3. Phototoxicity Studies. The phototoxicity of ALA and ALA-HPO conjugates, incubated with tumor cells for $4 \mathrm{~h}$ and irradiated with blue light $\left(2.5 \mathrm{~J} / \mathrm{cm}^{2}\right)$, was investigated over a range of concentrations between 2 and $100 \mu \mathrm{M}$. The data for $\mathrm{KB}$ cells are presented in Figure 5. The percentages of cell survival with respect to control cells (without compounds) were calculated for various concentrations of investigated compounds. In agreement with the data from the PpIX fluorescence experiments, the ALA-HPO conjugates that exhibited a marked enhancement of PpIX fluorescence also exhibited high phototoxicity. In general, compounds 7c, 7d, 7e, $\mathbf{7 f}$, and $\mathbf{2 3}$ were found to be the most phototoxic compounds at low concentrations.

The $\mathrm{LD}_{50}$ values (at $2.5 \mathrm{~J} / \mathrm{cm}^{2}$ ), calculated from Figure 5, are presented in Table 1 . The values for $7 \mathbf{d}, 7 \mathbf{e}$, and $7 \mathbf{f}$ are between $2.3 \mu \mathrm{M}$ and $12.9 \mu \mathrm{M}$ for all investigated cell lines, in contrast to the much higher value of $100 \mu \mathrm{M}$ for ALA. For 23, the $\mathrm{LD}_{50}$ values were somewhat higher, ranging between 11.3 and 19.6 $\mu \mathrm{M}$. The $\mathrm{LD}_{50}$ value of the hexyl ester of ALA (24) was found to be similar to that of 7e. Again, ALA-HPO conjugates in the present investigation were more phototoxic upon exposure to light than our previously reported compounds. For instance, after the incubation of $\mathrm{KB}$ cells with $7 \mathbf{d}, 7 \mathbf{e}$, and $7 \mathbf{f}(10 \mu \mathrm{M})$, followed by illumination, the survival percentages of $\mathrm{KB}$ cells were under $6 \%$, while the survival percentages of $\mathrm{KB}$ cells incubated with the previously reported best ALA-HPO compound $(200 \mu \mathrm{M})$ was $7.8 \% .^{37}$ The results of phototoxicity
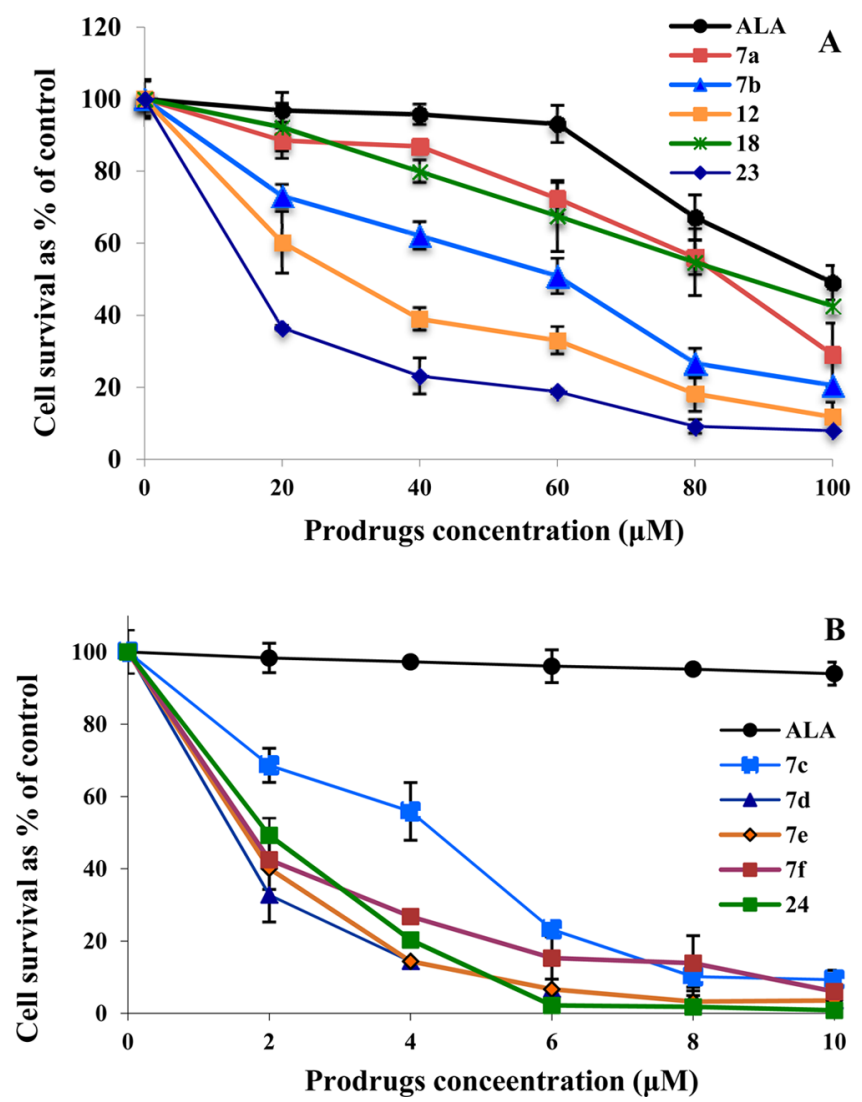

Figure 5. Phototoxicity over a range of ALA and ALA-HPO concentrations after $4 \mathrm{~h}$ incubation with the $\mathrm{KB}$ cell line, irradiated by $2.5 \mathrm{~J} / \mathrm{cm}^{2}$ blue light.

of ALA-HPO conjugates were in accordance with those of relative PpIX generation.

Phototoxicity was both drug concentration and irradiation dose dependent. Our results for the ALA hexyl ester are in accord with previous studies. For example, the hexyl ester was much more phototoxic than ALA against nasopharyngeal carcinoma (NPC) cells. ${ }^{41}$ To achieve an $80 \%$ death rate $\left(\mathrm{LD}_{80}\right), 0.75 \mathrm{mM}$ ALA and $6 \mathrm{~J} / \mathrm{cm}^{2}$ light dose were required, while only $0.03 \mathrm{mM}$ ALA hexyl ester and $4 \mathrm{~J} / \mathrm{cm}^{2}$ light dose were needed. In terms of overall photodynamic dose, the ALA hexyl ester is about 40 times more potent than ALA in cell inactivation. ${ }^{41}$ Although iron can affect the generation of ROS through redox processes, the high production of PpIX through the use of HPOs and improved PDT potency may predominate over any secondary factors related to the ability of iron to catalyze ROS generation/cascades following PpIX-induced PDT. Moreover, despite the reduction of iron availability, thereby increasing PpIX accumulation, other transition metals and freshly released labile iron may preserve the ROS cascades via Fenton reactions. ${ }^{46}$

2.2.4. Cell Viability and Dark Toxicity. The "dark" toxicity (namely, the cytotoxicity in the absence of irradiation) of the ALA-HPOs conjugates was also evaluated in the KB cells (Figure 6). The data indicated that there was no appreciable toxicity found for ALA or all the investigated compounds at 200 $\mu \mathrm{M}$ after $4 \mathrm{~h}$ or $24 \mathrm{~h}$ incubation.

The structural conjugates, where ALA is at one end and HPO moieties on the other end of the spacers, do not appear to induce significantly higher dark toxicity than ALA itself. In contrast, ALA ester derivatives, i.e., hexyl-ALA (24) and octyl- 


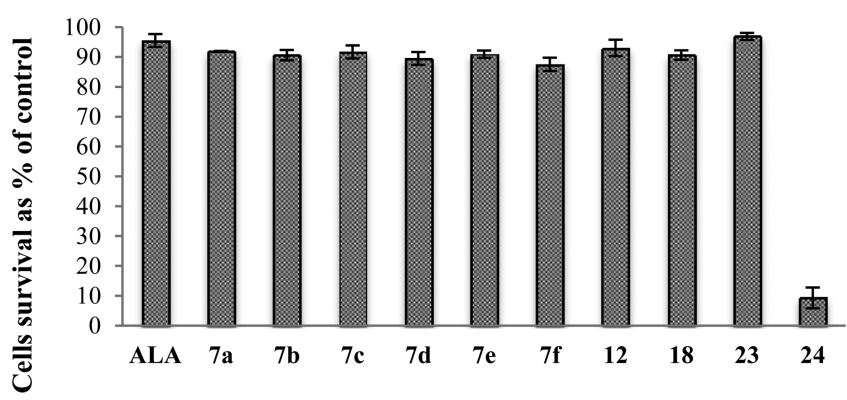

\section{ALA and Prodrug}

Figure 6. Dark toxicity of ALA, ALA-HPOs, and hexyl-ALA in KB cells incubated for $4 \mathrm{~h}$ without irradiation, then continued for $24 \mathrm{~h}$ after removal of the prodrugs.

ALA (25) showed significant dark toxicity ( $9 \%$ and $14 \%$ cell survival, respectively, at the lower concentration of $100 \mu \mathrm{M}$ after $4 \mathrm{~h}$ of incubation). The incubation of ALA-HPO conjugates for $24 \mathrm{~h}$ did not affect the cell viability more than a 4 $\mathrm{h}$ incubation. However, almost no cells survived after $24 \mathrm{~h}$ incubation with hexyl-ALA and octyl-ALA. It also appears with this assay that HPOs with the spacers $n=6$ or more elicit no chemical toxicity to the cells after cleavage and releasing ALA. The much lower dark toxicity of the HPO conjugate, albeit in a tumor cell line, is a significant finding in respect to the prodrug metabolism, particularly if it is to be considered for systemic administration, however, further in vivo studies will be required to validate lower dark toxicities.

\subsubsection{Intracellular Prodrug Quantitative Determination.}

The cellular uptake of the prodrugs and their intracellular conversion to ALA was assessed by quantitative determination of ALA using a HPLC-based fluorescence method. We adopted a previously reported derivatization method. ${ }^{17,45,47,48}$ A higher accumulation of ALA was observed after $2 \mathrm{~h}$ incubation at 100 $\mu \mathrm{M}$, particularly in $\mathrm{KB}$ and MCF-7R cells using the conjugates (Figure 7A). For example, 6- and 8-fold enhancements with 7d and $7 \mathbf{e}$ were observed with respect to ALA itself. These results were largely reflected in the intracellular PpIX levels measured at $24 \mathrm{~h}$ following $2 \mathrm{~h}$ incubation by fresh medium without ALA or prodrugs (Figure $7 \mathrm{~B}$ ).

The fluorescence intensity of PpIX in MCF-7R, which is a chemotherapy resistant breast cancer tumor cell line, elicited higher porphyrin levels than in the MCF-7 nonresistant counterpart, for the majority of ALA-HPO compounds. Malik and co-workers have also demonstrated that MCF-7R, doxorubicin resistant tumor cells, are capable of producing higher levels of porphyrins than sensitive MCF-7 cells due to the low expression of the enzyme ferrochelatase in combination with high mitochondrial activity. ${ }^{40}$ As found in the present study, higher PpIX levels than the doxorubicin sensitive MCF-7 cells were also observed.

\section{CONCLUSIONS}

ALA-PDT provides a promising therapy for many types of cancer, but it is important to improve its efficiency when ALA is administered systemically and intravenously in order to overcome inefficient cell uptake and conversion to PpIX. Iron chelating agents have been demonstrated to be effective at improving ALA-PDT by increasing the cellular PpIX accumulation. In the present study, a series of ALA-HPO conjugates were synthesized and tested in three cells lines. All ALA-HPO conjugates showed significantly elevated cellular
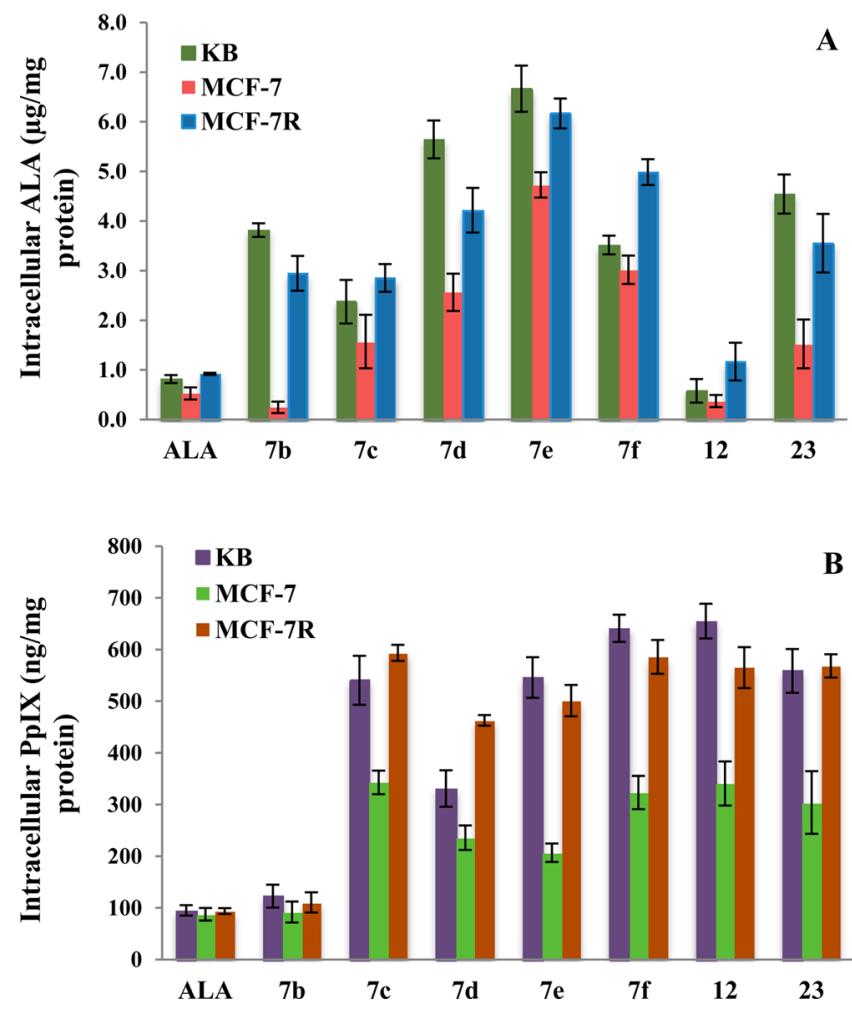

Figure 7. (A) Chemically extracted cellular concentrations per mg protein of intracellular ALA or ALA-HPOs with celLytic after $2 \mathrm{~h}$ incubation at $100 \mu \mathrm{M}$. (B) PpIX cellular concentrations per mg protein measured at $24 \mathrm{~h}$ by chemical extraction using cellytic following $2 \mathrm{~h}$ incubation with ALA and ALA-HPO conjugates at 37 ${ }^{\circ} \mathrm{C}$.

PpIX accumulation in KB, MCF-7, and MCF-7R cell lines when compared to ALA and a combination of ALA with the corresponding HPO. Overall, compound 7e, with a linker of $\left(\mathrm{CH}_{2}\right)_{10}$, was found to be the most effective in both enhancement of cellular PpIX levels and tumor cell phototoxicity, with comparable efficacy to the ALA hexyl ester.

\section{EXPERIMENTAL SECTION}

4.1. General. ${ }^{1} \mathrm{H}$ and ${ }^{13} \mathrm{C}$ NMR were recorded on a Jeol EX 270 $\mathrm{MHz}$ spectrometer (Jeol Ltd., Toxyo, Japan), or on Bruker Avance 400 or Bruker Avance 500 spectrometer. Chemical shifts are quoted in ppm measured downfield relative to TMS. Mass spectra were obtained using a EI/CI (electroionization/chemical ionization). Analytical thin layer chromatography was carried out using Adsorbentien, aluminumbacked, silica-coated plates (VWR, Germany) which were visualized using ultraviolet light $(254 \mathrm{~nm})$. Column chromatography was carried out using Alfa Aester silica gel (220-440 mesh flash grade). High performance liquid chromatography (HPLC) was performed on a $\mathrm{Si}$ (55w) $2502.1 \mathrm{~mm}$ column attached to a Agilent instrument (Agilent, Life Sciences \& Chemical Analysis Group, UK). All the chemicals were purchased from Aldrich, Fisher, Alfa Aester and Aladdin, and used without further purification unless otherwise stated. Analytical analysis was carried out by electrospray (ES) instrument (Quattro Premier XE, Micromass Technologies) which coupled to high performance liquid chromatograpy (HPLC, Waters/AcQuity Ultrapreformance LC, Waters, Manchester, UK). Electrospray ionization (ESI) mass spectra were obtained by infusing samples into an LCQ Deca XP ion trap instrument. High resolution mass spectra (HRMS) were determined on Waters QTOF micro. The purity of ALA-HPO conjugates was determined by analytical HPLC (Agilent system 1100) coupled with UV-vis/DAD (diode array detector) using C18 reverse-phase column [HYPERSIL $(5 \mu \mathrm{m}, 2.1 \mathrm{~mm} \times 150 \mathrm{~mm})]$. The total run was 
monitored with UV detector at two wavelengths 268 and $282 \mathrm{~nm}$. The purities of all the AlA-HPO conjugates were over $95 \%$.

4.2. Synthetic Procedures. 4.2.1. N-Benzyloxycarbonyl-5aminolevulinic Acid ( $N$-Cbz ALA). 5-Aminolaevulinic acid (0.22 g, $1.30 \mathrm{mmol}$ ) was dissolved in water $(3 \mathrm{~mL})$ and the solution was adjusted to $\mathrm{pH} 8-10$ with sodium carbonate solution. $\mathrm{N}$ Benzyloxycarbonyl chloride $(0.30 \mathrm{~mL}, 1.40 \mathrm{mmol})$ was dissolved in dioxane $(3 \mathrm{~mL})$ and added to the mixture. After $18 \mathrm{~h}$ at room temperature, the solvents were removed in vacuum and $0.1 \mathrm{M}$ of sodium hydroxide $(20 \mathrm{~mL})$ was added. The mixture was washed with diethyl ether three times. The aqueous layer was neutralized to $\mathrm{pH} 6$, and the product was extracted with dichloromethane $(5 \times 20 \mathrm{~mL})$. The organic layers were combined, dried with $\mathrm{Na}_{2} \mathrm{SO}_{4}$, and evaporated to yield the product as thick oil $(0.18 \mathrm{~g}, 52 \%) .{ }^{1} \mathrm{H}$ NMR $(270 \mathrm{MHz}$, $\left.\mathrm{CDCl}_{3}\right) \delta 2.73\left(\mathrm{~m}, 4 \mathrm{H}, \mathrm{CH}_{2}\right), 4.10\left(\mathrm{~s}, 2 \mathrm{H}, \mathrm{CH}_{2}\right), 5.12\left(\mathrm{~s}, 2 \mathrm{H}, \mathrm{CH}_{2}\right)$, $5.45(\mathrm{br}, 1 \mathrm{H}, \mathrm{NH}), 7.31(\mathrm{~m}, 5 \mathrm{H}, \mathrm{Ph}) .{ }^{13} \mathrm{C} \mathrm{NMR}\left(67.5 \mathrm{MHz}, \mathrm{CDCl}_{3}\right) \delta$ $27.02,34.20,46.61,65.54,71.33,127.66,127.86,128.94,138.31$, 155.00, 171.82. ESI-MS: $m / z 264\left([\mathrm{M}-\mathrm{H}]^{-}\right)$.

4.2.2. 3-(Benzyloxy)-2-ethyl-4H-pyran-4-one (2a). To a solution of ethyl maltol $(84 \mathrm{~g}, 0.6 \mathrm{~mol})$ in methanol $(300 \mathrm{~mL})$ was added $\mathrm{NaOH}$ solution ( $26.4 \mathrm{~g}$ in $80 \mathrm{~mL}$ of $\mathrm{H}_{2} \mathrm{O}$ ). The mixture was heated to reflux, and benzyl bromide $(85.6 \mathrm{~mL}, 0.72 \mathrm{~mol})$ was added dropwise over a 2 $\mathrm{h}$ period. The solution was maintained at $60-65{ }^{\circ} \mathrm{C}$ overnight. $\mathrm{NaBr}$ was removed by filtration, and the filtrate was concentrated. Dichloromethane $(400 \mathrm{~mL})$ was added to the residue and washed with $5 \% \mathrm{NaOH}$ solution $(3 \times 250 \mathrm{~mL})$ and $\mathrm{H}_{2} \mathrm{O}(2 \times 300 \mathrm{~mL})$ and dried over anhydrous $\mathrm{Na}_{2} \mathrm{SO}_{4}$. After removal of the solvent, diethyl ether $(100 \mathrm{~mL})$ was added to the residue and allowed to stand to $4{ }^{\circ} \mathrm{C}$. The product was obtained as white crystals $(91.2 \mathrm{~g}, 66 \%) .{ }^{1} \mathrm{H}$ NMR $\left(\mathrm{CDCl}_{3}, 400 \mathrm{MHz}\right) \delta 0.98\left(\mathrm{t}, J=7.6 \mathrm{~Hz}, 3 \mathrm{H}, \mathrm{CH}_{3}\right), 2.50(\mathrm{q}, J=7.6$ $\left.\mathrm{Hz}, 2 \mathrm{H}, \mathrm{CH}_{2}\right), 5.17\left(\mathrm{~s}, 2 \mathrm{H}, \mathrm{CH}_{2}\right), 6.37(\mathrm{~d}, J=5.6 \mathrm{~Hz}, 1 \mathrm{H}, \mathrm{C} 5-\mathrm{H}$ in pyridinone), $7.30-7.41(\mathrm{~m}, 5 \mathrm{H}, \mathrm{Ph}), 7.63(\mathrm{~d}, J=5.6 \mathrm{~Hz}, 1 \mathrm{H}, \mathrm{C} 6-\mathrm{H}$ in pyridinone). ESI-MS: $m / z 231\left([\mathrm{M}+\mathrm{H}]^{+}\right)$.

4.2.3. General Synthetic Procedure for Amino Alcohols (3). 8Aminooctan-1-ol (3d). To a mixture of 1,8-octanediol (13.3 g, 91 mmol), phthalimide $(8.92 \mathrm{~g}, 60.6 \mathrm{mmol})$, and triphenylphosphine $(15.89 \mathrm{~g}, 60.6 \mathrm{mmol})$ in tetrahydrofuran (THF) $(150 \mathrm{~mL})$, cooled on an ice-bath, was added dropwise diisopropyl azodicarboxylate (DIPAD) $(12.25 \mathrm{~g}, 60.0 \mathrm{mmol})$ over a period of $1 \mathrm{~h}$. The mixture was stirred at room temperature overnight. After removal of the solvent, the residue was purified by column chromatography using ethyl acetate/cyclohexane (1:2) as an eluent to obtain 2-(8hydroxyoctyl)isoindoline-1,3-dione $\left(\mathbf{3} \mathbf{d}^{\prime}\right)$ as a white solid (13.2 $\mathrm{g}$, $79 \%) .{ }^{1} \mathrm{H}$ NMR $\left(\mathrm{CDCl}_{3}, 400 \mathrm{MHz}\right) \delta 1.32\left(\mathrm{~m}, 8 \mathrm{H}, \mathrm{CH}_{2}\right), 1.53(\mathrm{~m}$, $\left.2 \mathrm{H}, \mathrm{CH}_{2}\right), 1.65\left(\mathrm{~m}, 2 \mathrm{H}, \mathrm{CH}_{2}\right), 3.61\left(\mathrm{t}, J=6.5 \mathrm{~Hz}, 2 \mathrm{H}, \mathrm{CH}_{2}\right), 3.66(\mathrm{t}, J$ $\left.=7.5 \mathrm{~Hz}, 2 \mathrm{H}, \mathrm{CH}_{2}\right), 7.69(\mathrm{~m}, 2 \mathrm{H}, \mathrm{Ph}), 7.82(\mathrm{~m}, 2 \mathrm{H}, \mathrm{Ph})$. ESI-MS: $m$ / $z 276\left([\mathrm{M}+\mathrm{H}]^{+}\right), 298\left([\mathrm{M}+\mathrm{Na}]^{+}\right)$.

To a solution of $3 \mathrm{~d}^{\prime}(12.5 \mathrm{~g}, 45.5 \mathrm{mmol})$ in $95 \%$ ethanol $(150 \mathrm{~mL})$ was added $50 \%$ hydrazine ( $4.35 \mathrm{~g}$ in $15 \mathrm{~mL} \mathrm{H}_{2} \mathrm{O}, 68.2 \mathrm{mmol}$ ). The mixture was refluxed for $3 \mathrm{~h}$, and then $10 \mathrm{M} \mathrm{HCl}(15 \mathrm{~mL})$ was added. Reflux was continued for a further $15 \mathrm{~min}$, cooled with an ice-bath, and then filtered. The filtrate was concentrated, and $15 \mathrm{~mL}$ of water was added and washed with diethyl ether. The aqueous layer was adjusted to $\mathrm{pH} 12$ with $10 \mathrm{M} \mathrm{NaOH}$ and then extracted with dichloromethane $(5 \times 120 \mathrm{~mL})$. The combined organic layer was dried over anhydrous $\mathrm{Na}_{2} \mathrm{SO}_{4}$. After removal of the solvent, 8-aminooctan-1-ol (3d) was obtained as a white solid $(5.41 \mathrm{~g}, 82 \%) .{ }^{1} \mathrm{H}$ NMR $\left(\mathrm{CDCl}_{3}, 500 \mathrm{MHz}\right) \delta$ $1.32\left(\mathrm{~m}, 8 \mathrm{H}, \mathrm{CH}_{2}\right), 1.45\left(\mathrm{~m}, 2 \mathrm{H}, \mathrm{CH}_{2}\right), 1.56\left(\mathrm{~m}, 2 \mathrm{H}, \mathrm{CH}_{2}\right), 2.58(\mathrm{t}, J$ $\left.=7.0 \mathrm{~Hz}, 2 \mathrm{H}, \mathrm{CH}_{2}\right), 2.68\left(\mathrm{t}, J=7.0 \mathrm{~Hz}, 2 \mathrm{H}, \mathrm{CH}_{2}\right), 3.63(\mathrm{t}, J=6.5 \mathrm{~Hz}$, 2H, $\left.\mathrm{CH}_{2}\right)$. ESI-MS: $m / z 146\left([\mathrm{M}+\mathrm{H}]^{+}\right)$.

2-(10-Hydroxydecyl)isoindoline-1,3-dione (3e'). ${ }^{1} \mathrm{H}$ NMR $\left(\mathrm{CDCl}_{3}, 500 \mathrm{MHz}\right) \delta 1.25\left(\mathrm{~m}, 10 \mathrm{H}, \mathrm{CH}_{2}\right), 1.31\left(\mathrm{~m}, 2 \mathrm{H}, \mathrm{CH}_{2}\right)$, $1.55\left(\mathrm{~m}, 2 \mathrm{H}, \mathrm{CH}_{2}\right), 1.66\left(\mathrm{~m}, 2 \mathrm{H}, \mathrm{CH}_{2}\right), 3.63\left(\mathrm{t}, J=6.5 \mathrm{~Hz}, 2 \mathrm{H}, \mathrm{CH}_{2}\right)$, $3.67\left(\mathrm{t}, J=7.5 \mathrm{~Hz}, 2 \mathrm{H}, \mathrm{CH}_{2}\right), 7.70(\mathrm{~m}, 2 \mathrm{H}, \mathrm{Ph}), 7.83(\mathrm{~m}, 2 \mathrm{H}, \mathrm{Ph})$. ESI-MS: $m / z 304\left([\mathrm{M}+\mathrm{H}]^{+}\right), 326\left([\mathrm{M}+\mathrm{Na}]^{+}\right)$.

10-Aminodecan-1-ol (3e). ${ }^{1} \mathrm{H}$ NMR $\left(\mathrm{CDCl}_{3}, 500 \mathrm{MHz}\right) \delta 1.28(\mathrm{~m}$, $\left.10 \mathrm{H}, \mathrm{CH}_{2}\right), 1.42\left(\mathrm{~m}, 4 \mathrm{H}, \mathrm{CH}_{2}\right), 1.55\left(\mathrm{~m}, 2 \mathrm{H}, \mathrm{CH}_{2}\right), 2.67(\mathrm{t}, J=7.0$ $\left.\mathrm{Hz}, 2 \mathrm{H}, \mathrm{CH}_{2}\right), 3.62\left(\mathrm{t}, J=6.5 \mathrm{~Hz}, 2 \mathrm{H}, \mathrm{CH}_{2}\right)$. ESI-MS: $m / z 174([\mathrm{M}+$ $\mathrm{H}]^{+}$).
2-(12-Hydroxydodecyl)isoindoline-1,3-dione $\left(3 f^{\prime}\right)$. ${ }^{1} \mathrm{H}$ NMR $\left(\mathrm{CDCl}_{3}, 500 \mathrm{MHz}\right) \delta 1.26\left(\mathrm{~m}, 16 \mathrm{H}, \mathrm{CH}_{2}\right), 1.32\left(\mathrm{~m}, 2 \mathrm{H}, \mathrm{CH}_{2}\right)$, $1.66\left(\mathrm{~m}, 2 \mathrm{H}, \mathrm{CH}_{2}\right), 3.63\left(\mathrm{t}, J=6.5 \mathrm{~Hz}, 2 \mathrm{H}, \mathrm{CH}_{2}\right), 3.67(\mathrm{t}, J=7.5 \mathrm{~Hz}$, $\left.2 \mathrm{H}, \mathrm{CH}_{2}\right), 7.70(\mathrm{~m}, 2 \mathrm{H}, \mathrm{Ph}), 7.84(\mathrm{~m}, 2 \mathrm{H}, \mathrm{Ph})$. ESI-MS: $\mathrm{m} / z 332$ ([M $\left.+\mathrm{H}]^{+}\right), 354\left([\mathrm{M}+\mathrm{Na}]^{+}\right)$.

12-Aminododecan-1-ol (3f). ${ }^{1} \mathrm{H}$ NMR $\left(\mathrm{CDCl}_{3}, 500 \mathrm{MHz}\right) \delta 1.27$ $\left(\mathrm{m}, 16 \mathrm{H}, \mathrm{CH}_{2}\right), 1.43\left(\mathrm{~m}, 2 \mathrm{H}, \mathrm{CH}_{2}\right), 1.55\left(\mathrm{~m}, 2 \mathrm{H}, \mathrm{CH}_{2}\right), 2.67(\mathrm{t}, J=$ $\left.7.0 \mathrm{~Hz}, 2 \mathrm{H}, \mathrm{CH}_{2}\right), 3.62\left(\mathrm{t}, J=6.5 \mathrm{~Hz}, 2 \mathrm{H}, \mathrm{CH}_{2}\right)$. ESI-MS: $m / z 202$ $\left([\mathrm{M}+\mathrm{H}]^{+}\right)$.

4.2.4. General Synthetic Procedure for Hydroxypyridinones (4). 3(Benzyloxy)-2-ethyl-1-(2-hydroxyethyl)pyridin-4(1H)-one (4a). Compound $2 \mathrm{a}(4.6 \mathrm{~g}, 20 \mathrm{mmol})$ was dissolved in ethanol $(30 \mathrm{~mL}) / \mathrm{H}_{2} \mathrm{O}(30$ $\mathrm{mL})$, followed by the addition of ethanolamine $(3.05 \mathrm{~g}, 50 \mathrm{mmol})$ and $2 \mathrm{M} \mathrm{NaOH}$ solution $(2 \mathrm{~mL})$. The mixture was refluxed for $18 \mathrm{~h}$. After cooling to room temperature, the solution was adjusted to $\mathrm{pH} 1$ with concentrated hydrochloric acid and then concentrated to half volume. Then $50 \mathrm{~mL}$ of $\mathrm{H}_{2} \mathrm{O}$ was added. The solution was washed with diethyl ether $(2 \times 50 \mathrm{~mL})$, adjusted to $\mathrm{pH} 9$ with $10 \mathrm{M} \mathrm{NaOH}$, and extracted with DCM $(3 \times 50 \mathrm{~mL})$. The combined organic layers were dried over anhydrous $\mathrm{Na}_{2} \mathrm{SO}_{4}$. After removal of the solvent, $4 \mathbf{a}$ was obtained by crystallization from ethyl acetate as yellow crystals $(4.06 \mathrm{~g}, 74 \%) .{ }^{1} \mathrm{H}$ $\operatorname{NMR}\left(\mathrm{CDCl}_{3}, 400 \mathrm{MHz}\right) \delta 0.96\left(\mathrm{t}, J=7.6 \mathrm{~Hz}, 3 \mathrm{H}, \mathrm{CH}_{3}\right), 2.68(\mathrm{q}, J=$ $\left.7.6 \mathrm{~Hz}, 2 \mathrm{H}, \mathrm{CH}_{2}\right), 3.86\left(\mathrm{~m}, 2 \mathrm{H}, \mathrm{CH}_{2}\right), 3.90\left(\mathrm{~m}, 2 \mathrm{H}, \mathrm{CH}_{2}\right), 5.06(\mathrm{~s}$, $\left.2 \mathrm{H}, \mathrm{CH}_{2}\right), 6.15(\mathrm{~d}, J=7.4 \mathrm{~Hz}, 1 \mathrm{H}, \mathrm{C} 5-\mathrm{H}$ in pyridinone), $7.30-7.40$ $(\mathrm{m}, 4 \mathrm{H}, \mathrm{Ph}$ and buried $\mathrm{C} 6-\mathrm{H}$ in pyridinone), $7.42(\mathrm{~m}, 2 \mathrm{H}, \mathrm{Ph})$. ESIMS: $m / z 274\left([\mathrm{M}+\mathrm{H}]^{+}\right), 296\left([\mathrm{M}+\mathrm{Na}]^{+}\right)$.

3-(Benzyloxy)-2-ethyl-1-(4-hydroxybutyl)pyridin-4(1H)-one (4b). Yield 69\%. ${ }^{1} \mathrm{H}$ NMR $\left(\mathrm{CDCl}_{3}, 400 \mathrm{MHz}\right) \delta 1.02(\mathrm{t}, J=7.6 \mathrm{~Hz}, 3 \mathrm{H}$, $\left.\mathrm{CH}_{3}\right), 1.54\left(\mathrm{~m}, 2 \mathrm{H}, \mathrm{CH}_{2}\right), 1.78\left(\mathrm{~m}, 2 \mathrm{H}, \mathrm{CH}_{2}\right), 2.57(\mathrm{q}, J=7.6 \mathrm{~Hz}, 2 \mathrm{H}$, $\left.\mathrm{CH}_{2}\right), 3.66\left(\mathrm{t}, J=6.0 \mathrm{~Hz}, 2 \mathrm{H}, \mathrm{CH}_{2}\right), 3.82\left(\mathrm{t}, J=7.6 \mathrm{~Hz}, 2 \mathrm{H}, \mathrm{CH}_{2}\right)$, $5.22\left(\mathrm{~s}, 2 \mathrm{H}, \mathrm{CH}_{2}\right), 6.36(\mathrm{~d}, J=7.6 \mathrm{~Hz}, 1 \mathrm{H}, \mathrm{C} 5-\mathrm{H}$ in pyridinone), 7.25 (d, $J=7.6 \mathrm{~Hz}, 1 \mathrm{H}, \mathrm{C} 6-\mathrm{H}$ in pyridinone), $7.28-7.35(\mathrm{~m}, 3 \mathrm{H}, \mathrm{Ph}), 7.41$ (m, 2H, Ph). ESI-MS: $m / z 302\left([\mathrm{M}+\mathrm{H}]^{+}\right), 324\left([\mathrm{M}+\mathrm{Na}]^{+}\right)$.

3-(Benzyloxy)-2-ethyl-1-(6-hydroxyhexyl)pyridin-4(1H)-one (4c). Yield 79\%. ${ }^{1} \mathrm{H}$ NMR $\left(\mathrm{CDCl}_{3}, 400 \mathrm{MHz}\right) \delta 1.03(\mathrm{t}, J=7.6 \mathrm{~Hz}, 3 \mathrm{H}$, $\left.\mathrm{CH}_{3}\right), 1.30-1.44\left(\mathrm{~m}, 4 \mathrm{H}, \mathrm{CH}_{2}\right), 1.56\left(\mathrm{~m}, 2 \mathrm{H}, \mathrm{CH}_{2}\right), 1.67(\mathrm{~m}, 2 \mathrm{H}$, $\left.\mathrm{CH}_{2}\right), 2.56\left(\mathrm{q}, J=7.6 \mathrm{~Hz}, 2 \mathrm{H}, \mathrm{CH}_{2}\right), 3.64\left(\mathrm{t}, J=6.4 \mathrm{~Hz}, 2 \mathrm{H}, \mathrm{CH}_{2}\right)$, $3.75\left(\mathrm{t}, J=7.6 \mathrm{~Hz}, 2 \mathrm{H}, \mathrm{CH}_{2}\right), 5.26\left(\mathrm{~s}, 2 \mathrm{H}, \mathrm{CH}_{2}\right), 6.41(\mathrm{~d}, J=7.6 \mathrm{~Hz}$, $1 \mathrm{H}, \mathrm{C} 5-\mathrm{H}$ in pyridinone), $7.18(\mathrm{~d}, J=7.6 \mathrm{~Hz}, 1 \mathrm{H}, \mathrm{C} 6-\mathrm{H}$ in pyridinone), $7.27-7.35(\mathrm{~m}, 3 \mathrm{H}, \mathrm{Ph}), 7.42(\mathrm{~m}, 2 \mathrm{H}, \mathrm{Ph})$. ESI-MS: $\mathrm{m} / z$ $330\left([\mathrm{M}+\mathrm{H}]^{+}\right), 352\left([\mathrm{M}+\mathrm{Na}]^{+}\right)$.

3-(Benzyloxy)-2-ethyl-1-(8-hydroxyoctyl)pyridin-4(1H)-one (4d). Yield 67\%. ${ }^{1} \mathrm{H}$ NMR $\left(\mathrm{CDCl}_{3}, 400 \mathrm{MHz}\right) \delta 1.03(\mathrm{t}, J=7.6 \mathrm{~Hz}, 3 \mathrm{H}$, $\left.\mathrm{CH}_{3}\right), 1.32\left(\mathrm{~m}, 8 \mathrm{H}, \mathrm{CH}_{2}\right), 1.56\left(\mathrm{~m}, 2 \mathrm{H}, \mathrm{CH}_{2}\right), 1.66\left(\mathrm{~m}, 2 \mathrm{H}, \mathrm{CH}_{2}\right)$, $2.57\left(\mathrm{q}, J=7.6 \mathrm{~Hz}, 2 \mathrm{H}, \mathrm{CH}_{2}\right), 3.64\left(\mathrm{t}, J=6.6 \mathrm{~Hz}, 2 \mathrm{H}, \mathrm{CH}_{2}\right), 3.74(\mathrm{t}, J$ $\left.=7.6 \mathrm{~Hz}, 2 \mathrm{H}, \mathrm{CH}_{2}\right), 5.28\left(\mathrm{~s}, 2 \mathrm{H}, \mathrm{CH}_{2}\right), 6.43(\mathrm{~d}, J=7.6 \mathrm{~Hz}, 1 \mathrm{H}, \mathrm{C} 5-\mathrm{H}$ in pyridinone), $7.17(\mathrm{~d}, J=7.6 \mathrm{~Hz}, 1 \mathrm{H}, \mathrm{C} 6-\mathrm{H}$ in pyridinone), $7.29-$ $7.35(\mathrm{~m}, 3 \mathrm{H}, \mathrm{Ph}), 7.43(\mathrm{~m}, 2 \mathrm{H}, \mathrm{Ph})$. ESI-MS: $m / z 358\left([\mathrm{M}+\mathrm{H}]^{+}\right)$, $380\left([\mathrm{M}+\mathrm{Na}]^{+}\right)$.

3-(Benzyloxy)-2-ethyl-1-(10-hydroxydecyl)pyridin-4(1H)-one (4e). Yield $63 \% .{ }^{1} \mathrm{H}$ NMR $\left(\mathrm{CDCl}_{3}, 500 \mathrm{MHz}\right) \delta 1.04(\mathrm{t}, J=7.5 \mathrm{~Hz}, 3 \mathrm{H}$, $\left.\mathrm{CH}_{3}\right), 1.29\left(\mathrm{~m}, 10 \mathrm{H}, \mathrm{CH}_{2}\right), 1.55\left(\mathrm{~m}, 2 \mathrm{H}, \mathrm{CH}_{2}\right), 1.66\left(\mathrm{~m}, 4 \mathrm{H}, \mathrm{CH}_{2}\right)$, $2.57\left(\mathrm{q}, J=7.5 \mathrm{~Hz}, 2 \mathrm{H}, \mathrm{CH}_{2}\right), 3.64\left(\mathrm{t}, J=6.5 \mathrm{~Hz}, 2 \mathrm{H}, \mathrm{CH}_{2}\right), 3.74(\mathrm{t}, J$ $\left.=7.5 \mathrm{~Hz}, 2 \mathrm{H}, \mathrm{CH}_{2}\right), 5.29\left(\mathrm{~s}, 2 \mathrm{H}, \mathrm{CH}_{2}\right), 6.42(\mathrm{~d}, J=7.5 \mathrm{~Hz}, 1 \mathrm{H}, \mathrm{C} 5-\mathrm{H}$ in pyridinone), $7.17(\mathrm{~d}, J=7.5 \mathrm{~Hz}, 1 \mathrm{H}, \mathrm{C} 6-\mathrm{H}$ in pyridinone), 7.29$7.35(\mathrm{~m}, 3 \mathrm{H}, \mathrm{Ph}), 7.44(\mathrm{~m}, 2 \mathrm{H}, \mathrm{Ph})$. ESI-MS: $m / z 386\left([\mathrm{M}+\mathrm{H}]^{+}\right)$, $408\left([\mathrm{M}+\mathrm{Na}]^{+}\right)$.

3-(Benzyloxy)-2-ethyl-1-(12-hydroxydodecyl)pyridin-4(1H)-one (4f). Yield $62 \% .{ }^{1} \mathrm{H}$ NMR $\left(\mathrm{CDCl}_{3}, 500 \mathrm{MHz}\right) \delta 1.04(\mathrm{t}, J=7.5 \mathrm{~Hz}$ $\left.3 \mathrm{H}, \mathrm{CH}_{3}\right), 1.28\left(\mathrm{~m}, 16 \mathrm{H}, \mathrm{CH}_{2}\right), 1.55\left(\mathrm{~m}, 2 \mathrm{H}, \mathrm{CH}_{2}\right), 1.66(\mathrm{~m}, 2 \mathrm{H}$, $\left.\mathrm{CH}_{2}\right), 2.57\left(\mathrm{q}, J=7.5 \mathrm{~Hz}, 2 \mathrm{H}, \mathrm{CH}_{2}\right), 3.64\left(\mathrm{t}, J=6.5 \mathrm{~Hz}, 2 \mathrm{H}, \mathrm{CH}_{2}\right)$, $3.74\left(\mathrm{t}, J=7.5 \mathrm{~Hz}, 2 \mathrm{H}, \mathrm{CH}_{2}\right), 5.28\left(\mathrm{~s}, 2 \mathrm{H}, \mathrm{CH}_{2}\right), 6.42(\mathrm{~d}, J=7.5 \mathrm{~Hz}$, $1 \mathrm{H}, \mathrm{C} 5-\mathrm{H}$ in pyridinone), $7.17(\mathrm{~d}, J=7.5 \mathrm{~Hz}, 1 \mathrm{H}, \mathrm{C} 6-\mathrm{H}$ in pyridinone), $7.29-7.35(\mathrm{~m}, 3 \mathrm{H}, \mathrm{Ph}), 7.43(\mathrm{~m}, 2 \mathrm{H}, \mathrm{Ph})$. ESI-MS: $m / z$ $414\left([\mathrm{M}+\mathrm{H}]^{+}\right), 436\left([\mathrm{M}+\mathrm{Na}]^{+}\right)$.

4.2.5. General Procedure for ALA Coupling to Pyridinones. NBenzyloxycarbonyl-5-aminolevulinic acid $(2.2 \mathrm{mmol})$ was dissolved in DCM $(20 \mathrm{~mL})$ and DMF $(5 \mathrm{~mL})$ under argon, DCC $(2 \mathrm{mmol})$, and DMAP $(0.2 \mathrm{mmol})$. The mixture was left to stir for $50 \mathrm{~min}$ at room temperature. Compound $4(2 \mathrm{mmol})$ was dissolved in DCM $(10 \mathrm{~mL})$ 
and added dropwise over $30 \mathrm{~min}$. The mixture was stirring overnight at room temperature. The heavy precipitate was filtered off, and the solvents were evaporated in vacuo. The residue was dissolved in DCM and washed with water then saturated sodium hydrogen carbonate. The solvent was removed, and the residue was purified by flash chromatography on silica gel using a gradient of petroleum ether/ethyl acetate (1:4), followed by $100 \%$ ethyl acetate and then methanol/ethyl acetate (1:9). The products 6 were isolated as yellow pastes with yields of $72-80 \%$.

2-(3-(Benzyloxy)-2-ethyl-4-oxopyridin-1(4H)-yl)ethyl-5(((benzyloxy)carbonyl)amino)-4-oxopentanoate (6a). Yield $77 \% .{ }^{1} \mathrm{H}$ NMR $\left(\mathrm{CDCl}_{3}, 270 \mathrm{MHz}\right) \delta 0.95\left(\mathrm{t}, J=7.6 \mathrm{~Hz}, 3 \mathrm{H} \mathrm{CH}_{3}\right), 2.47(\mathrm{~m}$, $\left.2 \mathrm{H}, \mathrm{CH}_{2}\right), 2.55\left(\mathrm{~m}, 2 \mathrm{H}, \mathrm{CH}_{2}\right), 2.59\left(\mathrm{q}, J=7.6 \mathrm{~Hz}, 2 \mathrm{H}, \mathrm{CH}_{2}\right), 3.95(\mathrm{~m}$, $\left.4 \mathrm{H}, \mathrm{CH}_{2}\right), 4.12\left(\mathrm{~s}, 2 \mathrm{H}, \mathrm{CH}_{2}\right), 5.01\left(\mathrm{~s}, 2 \mathrm{H}, \mathrm{CH}_{2}\right), 5.14\left(\mathrm{~s}, 2 \mathrm{H}, \mathrm{CH}_{2}\right)$, $6.30(\mathrm{~s}, 1 \mathrm{H}, \mathrm{NH}), 6.32(d, J=7.4,1 \mathrm{H}, \mathrm{C} 5-\mathrm{H}$ in pyridinone $), 7.2-7.36$ (m, $11 \mathrm{H}, 10 \mathrm{H}$ from $2 \mathrm{Ph}$ and $1 \mathrm{H}$ from $\mathrm{C} 6-\mathrm{H}$ in pyridinone). ${ }^{13} \mathrm{C}$ NMR: $\delta 13.2,17.7,27.7,34.5,49.9,50.6,62.6,66.8,71.7,117.2,123.3$, $127.9,128.1,128.3,128.6,128.7,136.1,138.5,142.0,142.4,146.2$, 156.2, 173.1, 173.5, 206.7. ESI-MS: $m / z 521\left([\mathrm{M}+\mathrm{H}]^{+}\right), 543([\mathrm{M}+$ $\left.\mathrm{Na}]^{+}\right)$.

4-(3-(Benzyloxy)-2-ethyl-4-oxopyridin-1(4H)-yl)butyl-5(((benzyloxy)carbonyl)amino)-4-oxopentanoate (6b). Yield $79 \% .{ }^{1} \mathrm{H}$ NMR $\left(\mathrm{CDCl}_{3}, 270 \mathrm{MHz}\right) \delta 0.95\left(\mathrm{t}, J=7.6 \mathrm{~Hz}, 3 \mathrm{H} \mathrm{CH}_{3}\right), 1.52(\mathrm{~m}$, $\left.2 \mathrm{H}, \mathrm{CH}_{2}\right), 1.67\left(\mathrm{~m}, 2 \mathrm{H}, \mathrm{CH}_{2}\right), 2.47\left(\mathrm{~m}, 2 \mathrm{H}, \mathrm{CH}_{2}\right), 2.49(\mathrm{~m}, 2 \mathrm{H}$, $\left.\mathrm{CH}_{2}\right), 2.52\left(\mathrm{q}, J=7.6 \mathrm{~Hz}, 2 \mathrm{H}, \mathrm{CH}_{2}\right), 3.63\left(\mathrm{~m}, 2 \mathrm{H}, \mathrm{CH}_{2}\right), 3.93(\mathrm{~m}, 4 \mathrm{H}$, $\left.\mathrm{CH}_{2}\right), 4.98\left(\mathrm{~s}, 2 \mathrm{H}, \mathrm{CH}_{2}\right), 5.11\left(\mathrm{~s}, 2 \mathrm{H}, \mathrm{CH}_{2}\right), 6.01(\mathrm{~s}, 1 \mathrm{H}, \mathrm{NH}), 6.31$ (d, $J=7.4,1 \mathrm{H}, \mathrm{C} 5-\mathrm{H}$ in pyridinone), $7.19-7.22(\mathrm{~m}, 11 \mathrm{H}, 10 \mathrm{H}$ from 2Ph and $1 \mathrm{H}$ from C6-H in pyridinone). ${ }^{13} \mathrm{C}$ NMR: $\delta 13.3,25.7,26.3$, 27.9, 28.5, 29.1, 31.5, 50.7, 53.3, 64.8, 66.9, 72.9, 76.8, 117.4, 127.9, $128.1,128.2,128.3,128.6,128.7,136.2,138.5,145.2,156.3,172.5$, 173.4, 204.0. ESI-MS: $m / z 549\left([\mathrm{M}+\mathrm{H}]^{+}\right) .571\left([\mathrm{M}+\mathrm{Na}]^{+}\right)$.

6-(3-(Benzyloxy)-2-ethyl-4-oxopyridin-1 (4H)-yl)hexyl-5(((benzyloxy)carbonyl)amino)-4-oxopentanoate (6c). Yield $80 \% .{ }^{1} \mathrm{H}$ NMR $\left(\mathrm{CDCl}_{3}, 270 \mathrm{MHz}\right) \delta 0.98\left(\mathrm{t}, J=7.6 \mathrm{~Hz}, 3 \mathrm{H}, \mathrm{CH}_{3}\right), 1.21-1.23$ $\left(\mathrm{m}, 4 \mathrm{H}, \mathrm{CH}_{2}\right), 1.52-1.55\left(\mathrm{~m}, 4 \mathrm{H}, \mathrm{CH}_{2}\right), 2.44-2.47\left(\mathrm{~m}, 4 \mathrm{H}, \mathrm{CH}_{2}\right)$, $3.63\left(\mathrm{q}, J=7.4 \mathrm{~Hz}, 2 \mathrm{H}, \mathrm{CH}_{2}\right), 3.84-3.98\left(\mathrm{~m}, 6 \mathrm{H}, \mathrm{CH}_{2}\right), 5.01(\mathrm{~s}, 2 \mathrm{H}$, $\left.\mathrm{CH}_{2}\right), 5.11\left(\mathrm{~s}, 2 \mathrm{H}, \mathrm{CH}_{2}\right), 6.02(\mathrm{br}, 1 \mathrm{H}, \mathrm{NH}), 6.31(\mathrm{~d}, J=7.4,1 \mathrm{H}, \mathrm{C} 5-$ $\mathrm{H}$ in pyridinone), 7.18 (d, $J=7.4 \mathrm{~Hz}, \mathrm{C} 6-\mathrm{H}$ in pyridinone), 7.21 (m, $10 \mathrm{H}, \mathrm{Ph}) .{ }^{13} \mathrm{C}$ NMR: $\delta 13.9,19.5,25.7,26.7,27.5,28.9,29.2,29.3$, 29.4, 31.7, 34.5, 49.9, 50.7, 52.6, 65.0, 67.0, 71.2, 117.5 127.9, 128.2, $128.8136 .4,138.1,138.5,142.0,156.2,172.5,173.1,206.7$. ESI-MS: $m / z 577\left([\mathrm{M}+\mathrm{H}]^{+}\right), 599\left([\mathrm{M}+\mathrm{Na}]^{+}\right)$.

8-(3-(Benzyloxy)-2-ethyl-4-oxopyridin-1(4H)-yl)octyl 5(((benzyloxy)carbonyl)amino)-4-oxopentanoate (6d). Yield 75\%. ${ }^{1} \mathrm{H}$ NMR $\left(\mathrm{CDCl}_{3}, 270 \mathrm{MHz}\right) \delta 1.02\left(\mathrm{t}, J=7.6 \mathrm{~Hz}, 3 \mathrm{H}, \mathrm{CH}_{3}\right), 1.29$ $\left(\mathrm{m}, 8 \mathrm{H}, \mathrm{CH}_{2}\right), 1.63\left(\mathrm{~m}, 4 \mathrm{H}, \mathrm{CH}_{2}\right), 2.55-2.70\left(\mathrm{~m}, 6 \mathrm{H}, \mathrm{CH}_{2}\right), 3.75(\mathrm{~m}$ $\left.2 \mathrm{H}, \mathrm{CH}_{2}\right), 4.03-4.13\left(\mathrm{~m}, 4 \mathrm{H}, \mathrm{CH}_{2}\right), 5.09\left(\mathrm{~s}, 2 \mathrm{H}, \mathrm{CH}_{2}\right), 5.25(\mathrm{~s}, 2 \mathrm{H}$, $\left.\mathrm{CH}_{2}\right), 5.57(\mathrm{br}, 1 \mathrm{H}, \mathrm{NH}), 6.49(\mathrm{~d}, 1 \mathrm{H}, J=7.4 \mathrm{~Hz}, 1 \mathrm{H}, \mathrm{C} 5-\mathrm{H}$ in pyridinone), $7.28-7.64(\mathrm{~m}, 11 \mathrm{H}, 2 \mathrm{Ph}$ and $\mathrm{C} 6-\mathrm{H}$ in pyridinone $) .{ }^{13} \mathrm{C}$ NMR: $\delta 13.4,20.2,25.9,26.5,27.9,28.2,28.6,29.2,29.3,29.4,31.5$, 50.7, 53.3, 64.8, 67.0, 72.9, 117.5, 127.9, 128.1, 128.3, 128.5, 128.6, 128.8, 134.2, 137.9, 138.1, 146.8, 156.3, 172.6, 173.6, 204.1. ESI-MS: $\mathrm{m} / z, 605\left([\mathrm{M}+\mathrm{H}]^{+}\right), 627\left([\mathrm{M}+\mathrm{Na}]^{+}\right)$.

10-(3-(Benzyloxy)-2-ethyl-4-oxopyridin-1(4H)-yl)decyl 5(((benzyloxy)carbonyl)amino)-4-oxopentanoate (6e). Yield $72 \%$. ${ }^{1} \mathrm{H}$ NMR $\left(\mathrm{CDCl}_{3}, 270 \mathrm{MHz}\right) \delta 1.02\left(\mathrm{t}, J=7.6 \mathrm{~Hz}, 3 \mathrm{H}, \mathrm{CH}_{3}\right), 1.24$ $\left(\mathrm{m}, 12 \mathrm{H}, \mathrm{CH}_{2}\right), 1.56\left(\mathrm{~m}, 4 \mathrm{H}, \mathrm{CH}_{2}\right), 2.51-2.66\left(\mathrm{~m}, 6 \mathrm{H}, \mathrm{CH}_{2}\right), 3.7(\mathrm{~m}$, $\left.2 \mathrm{H}, \mathrm{CH}_{2}\right), 4.01-4.09\left(\mathrm{~m}, 4 \mathrm{H}, \mathrm{CH}_{2}\right), 4.95\left(\mathrm{~s}, 2 \mathrm{H}, \mathrm{CH}_{2}\right), 5.23(\mathrm{~s}, 2 \mathrm{H}$, $\left.\mathrm{CH}_{2}\right), 5.69(\mathrm{br}, 1 \mathrm{H}, \mathrm{NH}), 6.36(\mathrm{~d}, J=7.4,1 \mathrm{H}, \mathrm{C} 5-\mathrm{H}$ in pyridinone), $7.12(\mathrm{~d}, J=7.4,1 \mathrm{H}, \mathrm{C} 6-\mathrm{H}$ in pyridinone), $7.26-7.31(\mathrm{~m}, 10 \mathrm{H}, \mathrm{Ph})$. ${ }^{13} \mathrm{C}$ NMR: $\delta 13.4,20.3,25.9,26.5,27.3,27.9,28.2,28.6,28.9,29.2$, 29.3, 29.4, 31.5, 50.7, 53.3, 64.8, 67.0, 72.9, 117.5, 127.9, 128.1, 128.3, $128.5,128.6,128.8,134.2,137.9,138.1,146.2,156.3,172.6,173.6$, 204.1. ESI-MS: $m / z 633\left([\mathrm{M}+\mathrm{H}]^{+}\right), 655\left([\mathrm{M}+\mathrm{Na}]^{+}\right)$.

12-(3-(Benzyloxy)-2-ethyl-4-oxopyridin-1(4H)-yl)dodecyl 5(((benzyloxy)carbonyl)amino)-4-oxopentanoate (6f). Yield $73 \%$. ${ }^{1} \mathrm{H} \mathrm{NMR}\left(\mathrm{CDCl}_{3}, 270 \mathrm{MHz}\right) \delta 0.98\left(\mathrm{t}, J=7.6 \mathrm{~Hz}, 3 \mathrm{H}, \mathrm{CH}_{3}\right), 1.03$ (m, 16H, $\left.\mathrm{CH}_{2}\right), 1.57-1.60\left(\mathrm{~m}, 4 \mathrm{H}, \mathrm{CH}_{2}\right), 2.53-2.64\left(\mathrm{~m}, 6 \mathrm{H}, \mathrm{CH}_{2}\right)$, $3.71\left(\mathrm{q}, J=7.4 \mathrm{~Hz}, 2 \mathrm{H}, \mathrm{CH}_{2}\right), 4.02\left(\mathrm{~m}, 2 \mathrm{H}, \mathrm{CH}_{2}\right), 4,11\left(\mathrm{~s}, 2 \mathrm{H}, \mathrm{CH}_{2}\right)$, $5.06\left(\mathrm{~s}, 2 \mathrm{H}, \mathrm{CH}_{2}\right), 5.24\left(\mathrm{~s}, 2 \mathrm{H}, \mathrm{CH}_{2}\right), 5.59(\mathrm{br}, 1 \mathrm{H}, \mathrm{NH}), 6.40(\mathrm{~d}, J=$
$7.4 \mathrm{~Hz}, 1 \mathrm{H}, \mathrm{C} 5-\mathrm{H}$ in pyridinone), 7.28 (d, $J=7.4 \mathrm{~Hz}, 1 \mathrm{H}, \mathrm{C} 6-\mathrm{H}$ in pyridinone), $7.30-7.39$ (m, 10H, Ph). ${ }^{13} \mathrm{C}$ NMR: $\delta 13.3,20.1,25.9$, 26.4, 27.6, 28.2, 28.6, 28.9, 29.2, 29.4, 29.5, 29.7, 31.6, 50.7, 53.3, 60.5, 65.0, 67.0, 72.9, 117.5, 128.8, 127.9, 128.1, 128.2, 128.6, 128.8, 136.5, $137.9,138.7,145.6,156.3,172.5,173.6,204.1$. ESI-MS: $m / z 661$ ([M $\left.+\mathrm{H}]^{+}\right), 683\left([\mathrm{M}+\mathrm{Na}]^{+}\right)$.

4.2.6. General Procedure for the Deprotection of Amino and Hydroxyl Groups of ALA-HPO Conjugates. Compounds 6a-6f, 11, 17, and 22 (1 equiv) were dissolved in methanol/ethyl acetate $(50 \mathrm{~mL}$, $1: 4)$. Catalytic amount of palladium on carbon $(5 \% \mathrm{Pd} / \mathrm{C}, 10 \%$ weight of protected ALA-HPO conjugates) and benzyl chloride (2.2 equiv) were added. The hydrogenation was carried out under $40 \mathrm{psi}_{2}$ at room temperature for $10 \mathrm{~min}$. $\mathrm{Pd} / \mathrm{C}$ was filtered off, and the filtrate was evaporated to dryness. The residues were purified by semipreparative Agilent HPLC using reverse-phase Waters column (4.6 $\mathrm{mm} \times 250 \mathrm{~mm})$ eluted with acetonitrile/methanol $(30: 70, \mathrm{~V} / \mathrm{V})$ with flow rate $1 \mathrm{~mL} / \mathrm{min}$. ALA-HPO conjugates $7,12,18$, and 23 were isolated as thick oils. The purity of all compounds was determined by analytical HPLC (Agilent system 1100) coupled with UV-vis/DAD using C18 reverse-phase column [HYPERSIL $(5 \mu \mathrm{m}, 2.1 \mathrm{~mm} \times 150$ $\mathrm{mm})]$. The mobile phase was A (0.1\% TFA in $\left.\mathrm{MeOH}: \mathrm{H}_{2} \mathrm{O}, 2: 98\right)$, $100 \%$ isocratic for $5 \mathrm{~min}, \mathrm{~B}\left(0.1 \%\right.$ TFA in $\left.\mathrm{MeOH}: \mathrm{H}_{2} \mathrm{O}, 98: 2\right)$, gradient from 0 to $50 \%$ between 6 and $10 \mathrm{~min}, 50 \% \mathrm{~B}$ isocratic from 11 to 15 min, then equilibrated with $100 \%$ A for $2 \mathrm{~min}$. The total elution time was $18 \mathrm{~min}$ and flow rate was $0.25 \mathrm{~mL} / \mathrm{min}$. The total run was monitored with UV detector at two wavelengths 268 and $282 \mathrm{~nm}$.

(2-(2-Ethyl-3-hydroxy-4-oxopyridin-1(4H)-yl)ethoxy)-2,5-dioxopentan-1-aminium Chloride (7a). The product was isolated as thick oil, yield 35\%, HPLC-DAD ( $R_{\mathrm{t}}: 2.3 \mathrm{~min}$; purity 95.6\%). ${ }^{1} \mathrm{H}$ NMR (DMSO, $270 \mathrm{MHz}) \delta 1.23\left(\mathrm{t}, J=7.5 \mathrm{~Hz}, 3 \mathrm{H}, \mathrm{CH}_{3}\right), 2.64(\mathrm{~m}, 2 \mathrm{H}$, $\left.\mathrm{CH}_{2}\right), 2.85\left(\mathrm{~m}, 2 \mathrm{H}, \mathrm{CH}_{2}\right), 3.06\left(\mathrm{~m}, 2 \mathrm{H}, \mathrm{CH}_{2}\right), 3.59\left(\mathrm{~m}, 2 \mathrm{H}, \mathrm{CH}_{2}\right)$, $4.02\left(\mathrm{~s}, 2 \mathrm{H}, \mathrm{CH}_{2}\right), 4.38\left(\mathrm{~m}, 2 \mathrm{H}, \mathrm{CH}_{2}\right), 7.13(\mathrm{~d}, J=6.7 \mathrm{~Hz}, 1 \mathrm{H}, \mathrm{C} 5-\mathrm{H}$ in pyridinone), $7.66\left(\mathrm{~m}, 3 \mathrm{H}, \mathrm{H}_{3} \mathrm{~N}^{+}\right), 8.10(\mathrm{~d}, J=6.9 \mathrm{~Hz}, 1 \mathrm{H}, \mathrm{C} 6-\mathrm{H}$ in pyridinone). ${ }^{13} \mathrm{C}$ NMR: $\delta 12.1,15.3,27.7,36.2,44.3,53.7,55.5,113.3$ 127.9, 134.0, 143.0, 164.9, 172.1, 206.2. ESI-MS: $m / z 297\left([\mathrm{M}+\mathrm{H}]^{+}\right)$. HRMS: calcd for $\mathrm{C}_{14} \mathrm{H}_{21} \mathrm{~N}_{2} \mathrm{O}_{5}, 297.1450\left([\mathrm{M}+\mathrm{H}]^{+}\right)$; found, 297.1441 .

5-(4-(2-Ethyl-3-hydroxy-4-oxopyridin-1(4H)-yl)butoxy)-2,5-dioxopentan-1-aminium Chloride (7b). Yield 42\%, HPLC-DAD $\left(R_{t}: 3.2\right.$ min; purity 96.3\%). ${ }^{1} \mathrm{H}$ NMR $\left(\mathrm{CD}_{3} \mathrm{OH}, 270 \mathrm{MHz}\right) \delta 1.26(\mathrm{t}, J=7.1$ $\left.\mathrm{Hz}, 3 \mathrm{H}, \mathrm{CH}_{3}\right), 1.82\left(\mathrm{~m}, 2 \mathrm{H}, \mathrm{CH}_{2}\right) 1.98\left(\mathrm{~m}, 2 \mathrm{H} \mathrm{CH}_{2}\right), 2.64(\mathrm{~m}, 2 \mathrm{H}$, $\left.\mathrm{CH}_{2}\right), 2.83\left(\mathrm{~m}, 2 \mathrm{H}, \mathrm{CH}_{2}\right), 3.06\left(\mathrm{q}, J=5.4 \mathrm{~Hz}, 2 \mathrm{H}, \mathrm{CH}_{2}\right), 4.09(\mathrm{~m}, 4 \mathrm{H}$, $\left.\mathrm{CH}_{2}\right), 4.43\left(\mathrm{~m}, 2 \mathrm{H}, \mathrm{CH}_{2}\right), 7.12(\mathrm{~d}, J=6.4 \mathrm{~Hz}, 1 \mathrm{H}, \mathrm{C} 5-\mathrm{H}$ in pyridinone), 8.32 (d, $J=6.7 \mathrm{~Hz}, 1 \mathrm{H}, \mathrm{C} 6-\mathrm{H}$ in pyridinone) ${ }^{13} \mathrm{C}$ NMR: $\delta 11.1,15.3,19.4,26.8,27.1,36.2,50.3,52.6,64.4,116.8,126.2,137.4$, 140.5 , 156.2, 172.2, 201.2. ESI-MS: $m / z 325\left([\mathrm{M}+\mathrm{H}]^{+}\right), 347([\mathrm{M}+$ $\left.\mathrm{Na}]^{+}\right)$. HRMS: calcd for $\mathrm{C}_{16} \mathrm{H}_{25} \mathrm{~N}_{2} \mathrm{O}_{5}, 325.1763\left([\mathrm{M}+\mathrm{H}]^{+}\right)$; found, 325.1743 .

5-((6-(2-Ethyl-3-hydroxy-4-oxopyridin-1(4H)-yl)hexyl)oxy)-2,5-dioxopentan-1-aminium Chloride (7c). Yield 42\%, HPLC-DAD ( $R_{\mathrm{t}}$ : $3.7 \mathrm{~min}$; purity 96.6\%). ${ }^{1} \mathrm{H} \mathrm{NMR}\left(\mathrm{CD}_{3} \mathrm{OH}, 270 \mathrm{MHz}\right) \delta 1.29(\mathrm{t}, J=$ $\left.7.1 \mathrm{~Hz}, 3 \mathrm{H}, \mathrm{CH}_{3}\right), 1.45\left(\mathrm{~m}, 4 \mathrm{H}, \mathrm{CH}_{2}\right) 1.89\left(\mathrm{~m}, 4 \mathrm{H}, \mathrm{CH}_{2}\right), 2.67(\mathrm{~m}$, $\left.4 \mathrm{H}, \mathrm{CH}_{2}\right), 2.82\left(\mathrm{~m}, 2 \mathrm{H}, \mathrm{CH}_{2}\right), 3.29\left(\mathrm{~m}, 2 \mathrm{H}, \mathrm{CH}_{2}\right), 3.55(\mathrm{~m}, 2 \mathrm{H}$, $\left.\mathrm{CH}_{2}\right), 4.06\left(\mathrm{~m}, 2 \mathrm{H}, \mathrm{CH}_{2}\right), 7.15(\mathrm{~d}, J=6.4 \mathrm{~Hz}, 1 \mathrm{H}, \mathrm{C} 5-\mathrm{H}$ in pyridinone), $8.20(\mathrm{~d}, J=6.7 \mathrm{~Hz}, 1 \mathrm{H}, \mathrm{C} 6-\mathrm{H}$ in pyridinone $) .{ }^{13} \mathrm{C}$ NMR: $\delta 11.1,15.2,19.4,25.4,26.8,29.1,34.2,36.2,50.3,52.6,64.4,111.9$ $136.4,138.5,156.2,172.2,173.1,201.2$. ESI-MS: $m / z 353.3([\mathrm{M}+$ $\left.\mathrm{H}]^{+}\right), 375.3\left([\mathrm{M}+\mathrm{Na}]^{+}\right)$. HRMS: calcd for $\mathrm{C}_{18} \mathrm{H}_{29} \mathrm{~N}_{2} \mathrm{O}_{5}, 353.2076$ $\left([\mathrm{M}+\mathrm{H}]^{+}\right)$; found, 353.2065.

5-((8-(2-Ethyl-3-hydroxy-4-oxopyridin-1(4H)-yl)octyl)oxy)-2,5-dioxopentan-1-aminium) Dichloride (7d). Yield 48\%, HPLC-DAD $\left(R_{\mathrm{t}}\right.$ : $4.3 \mathrm{~min}$; purity 97.7\%). ${ }^{1} \mathrm{H} \mathrm{NMR}\left(\mathrm{CD}_{3} \mathrm{OH}, 270 \mathrm{MHz}\right) \delta 1.17(\mathrm{t}, 3 \mathrm{H}, J$ $\left.=7.1 \mathrm{~Hz}, \mathrm{CH}_{3}\right), 1.26\left(\mathrm{~m}, 12 \mathrm{H}, \mathrm{CH}_{2}\right), 2.66\left(\mathrm{~m}, 2 \mathrm{H}, \mathrm{CH}_{2}\right), 2.85(\mathrm{~m}$, $\left.2 \mathrm{H}, \mathrm{CH}_{2}\right), 3.49\left(\mathrm{~m}, 2 \mathrm{H}, \mathrm{CH}_{2}\right), 3.61,\left(\mathrm{~m}, 2 \mathrm{H}, \mathrm{CH}_{2}\right), 4.05-4.11(\mathrm{~m}$, $\left.4 \mathrm{H}, \mathrm{CH}_{2}\right), 7.33(\mathrm{~d}, J=6.4 \mathrm{~Hz}, 1 \mathrm{H}, \mathrm{C} 5-\mathrm{H}$ in pyridinone) $8.22(\mathrm{~d}, J=$ $6.7 \mathrm{~Hz}, 1 \mathrm{H}, \mathrm{C} 6-\mathrm{H}$ in pyridinone). ${ }^{13} \mathrm{C}$ NMR: $\delta 11.3,19.9,25.7,26.4$, 29.0, 29.1, 31.3, 34.2, 36.2, 50.3, 52.6, 64.4, 110.8 138.4, 143.4, 146.4, 158.4, 172.9, 201.7. ESI-MS: $m / z 382.1\left([\mathrm{M}+\mathrm{H}]^{+}\right), 404.2([\mathrm{M}+$ $\mathrm{Na}]^{+}$). HRMS: calcd for $\mathrm{C}_{20} \mathrm{H}_{33} \mathrm{~N}_{2} \mathrm{O}_{5}, 381.2389\left([\mathrm{M}+\mathrm{H}]^{+}\right)$; found, 381.2383. 
5-((10-(2-Ethyl-3-hydroxy-4-oxopyridin-1(4H)-yl)decyl)oxy)-2,5dioxopentan-1-aminium Chloride (7e). Yield 45\%, HPLC-DAD $\left(R_{\mathrm{t}}\right.$ : 5.4 min; purity 97.4\%). ${ }^{1} \mathrm{H}$ NMR $\left(\mathrm{CD}_{3} \mathrm{OH}, 270 \mathrm{MHz}\right) \delta 1.17(\mathrm{t}, J=$ $\left.7.1 \mathrm{~Hz}, 3 \mathrm{H}, \mathrm{CH}_{3}\right), 1.26\left(\mathrm{~m}, 16 \mathrm{H}, \mathrm{CH}_{2}\right), 2.66\left(\mathrm{~m}, 2 \mathrm{H}, \mathrm{CH}_{2}\right), 2.85(\mathrm{~m}$, $\left.2 \mathrm{H}, \mathrm{CH}_{2}\right), 3.15\left(\mathrm{~m}, 2 \mathrm{H}, \mathrm{CH}_{2}\right), 3.91\left(\mathrm{~m}, 2 \mathrm{H}, \mathrm{CH}_{2}\right), 4.05\left(\mathrm{~s}, 2 \mathrm{H}, \mathrm{CH}_{2}\right)$, $4.60\left(\mathrm{~m}, 2 \mathrm{H}, \mathrm{CH}_{2}\right), 7.15(\mathrm{~d}, J=6.4 \mathrm{~Hz}, 1 \mathrm{H}, \mathrm{C} 5-\mathrm{H}$ in pyridinone $), 8.20$ (d, $J=6.7 \mathrm{~Hz}, 1 \mathrm{H}, \mathrm{C} 6-\mathrm{H}$ in pyridinone). ${ }^{13} \mathrm{C}$ NMR: $\delta 11.3,19.8,25.0$, 26.4, 29.0, 29.1, 29.3, 31.2, 34.2, 50.3, 52.6, 56.4, 61.7, 64.7, 110.8, 138.4, 143.5, 146.0, 158.2, 172.9, 201.2. ES-MS: $409.2\left([\mathrm{M}+\mathrm{H}]^{+}\right)$. HRMS: calcd for $\mathrm{C}_{22} \mathrm{H}_{37} \mathrm{~N}_{2} \mathrm{O}_{5}, 409.2702\left([\mathrm{M}+\mathrm{H}]^{+}\right)$; found, 409.2700 .

5-((12-(2-Ethyl-3-hydroxy-4-oxopyridin-1(4H)-yl)dodecyl)oxy)2,5-dioxopentan-1-aminium Chloride (7f). Yield 43\%, HPLC-DAD $\left(R_{\mathrm{t}}: 6.2 \mathrm{~min}\right.$; purity 96.8\%). ${ }^{1} \mathrm{H} \mathrm{NMR}\left(\mathrm{CD}_{3} \mathrm{OH}, 270 \mathrm{MHz}\right) \delta 1.11(\mathrm{t}, J$ $\left.=7.1 \mathrm{~Hz}, 3 \mathrm{H}, \mathrm{CH}_{3}\right), 1.13\left(\mathrm{~m}, 20 \mathrm{H}, \mathrm{CH}_{2}\right), 2.66\left(\mathrm{~m}, 2 \mathrm{H}, \mathrm{CH}_{2}\right), 2.90$ (m, $\left.2 \mathrm{H}, \mathrm{CH}_{2}\right), 3.32\left(\mathrm{~m}, 2 \mathrm{H}, \mathrm{CH}_{2}\right), 3.91\left(\mathrm{~m}, 2 \mathrm{H}, \mathrm{CH}_{2}\right), 4.09(\mathrm{~s}, 2 \mathrm{H}$, $\left.\mathrm{CH}_{2}\right), 4.60\left(\mathrm{~m}, 2 \mathrm{H}, \mathrm{CH}_{2}\right), 7.33(\mathrm{~d}, J=6.4 \mathrm{~Hz}, 1 \mathrm{H}, \mathrm{C} 5-\mathrm{H}$ in pyridinone), 8.22 (d, $J=6.7 \mathrm{~Hz}, 1 \mathrm{H}, \mathrm{C} 6-\mathrm{H}$ in pyridinone). ${ }^{13} \mathrm{C}$ NMR: $\delta$ 11.3, 19.8, 25.7, 26.1, 28.7, 28.9, 29.0, 29.1, 29.3, 31.3, 32.4, 34.2, $50.2,52.3,56.4,61.7,64.7,110.7,138.1,143.5,146.4,158.4,172.9$, 201.2. ESI-MS: $m / z 437.0\left([\mathrm{M}+\mathrm{H}]^{+}\right)$, $459.1\left([\mathrm{M}+\mathrm{Na}]^{+}\right)$. HRMS: calcd for $\mathrm{C}_{24} \mathrm{H}_{41} \mathrm{~N}_{2} \mathrm{O}_{5}, 437.3015\left([\mathrm{M}+\mathrm{H}]^{+}\right)$; found, 437.3025.

4.2.7. Synthesis of ALA-HPO Conjugate 12. 3-(Benzyloxy)-2-(1hydroxyethyl)-4H-pyran-4-one (8). A mixture of 3-(benzyloxy)-2ethyl-4H-pyran-4-one (2a) (10g, $43.4 \mathrm{mmol}), \mathrm{SeO}_{2}(14.5 \mathrm{~g}, 130.4$ $\mathrm{mmol})$, and phenyl bromide $(50 \mathrm{~mL})$ was heated to $135-140{ }^{\circ} \mathrm{C}$ with vigorous stirring for $4 \mathrm{~h}$. After filtration, the filtrate was concentrated and the residue was purified by column chromatography using ethyl acetate/cycle hexane $(2: 1)$ as an eluent to obtain product as a brown oil (4.6 g, 43\%). ${ }^{1} \mathrm{H}$ NMR $\left(\mathrm{CDCl}_{3}, 400 \mathrm{MHz}\right) \delta 1.23(\mathrm{~d}, J=6.7 \mathrm{~Hz}$, $\left.3 \mathrm{H}, \mathrm{CH}_{3}\right), 4.85(\mathrm{q}, J=6.7 \mathrm{~Hz}, 1 \mathrm{H}, \mathrm{CH}), 5.22(\mathrm{~d}, J=2.0 \mathrm{~Hz}, 2 \mathrm{H}$, $\left.\mathrm{CH}_{2}\right), 6.46(\mathrm{~d}, \mathrm{~J}=5.6 \mathrm{~Hz}, 1 \mathrm{H}, \mathrm{C} 5-\mathrm{H}$ in pyridinone), $7.37(\mathrm{~m}, 5 \mathrm{H}, \mathrm{Ph})$, $7.71(\mathrm{~d}, J=5.6 \mathrm{~Hz}, 1 \mathrm{H}, \mathrm{C} 6-\mathrm{H}$ in pyridinone). ESI-MS: $m / z 247$ ([M+ $\left.\mathrm{H}]^{+}\right)$.

3-(Benzyloxy)-2-(1-(benzyloxy)ethyl)-4H-pyran-4-one (9). To a solution of 3-(benzyloxy)-2-(1-hydroxyethyl)-4H-pyran-4-one (8) $(4.0 \mathrm{~g}, 16.2 \mathrm{mmol})$ in dichloromethane $(50 \mathrm{~mL})$ was added $50 \%$ $\mathrm{KOH}(5.45 \mathrm{~g}, 48.6 \mathrm{mmol})$ and $\mathrm{Bu}_{4} \mathrm{~N}^{+} \mathrm{HSO}_{4}{ }^{-}(0.1 \mathrm{~g})$. The mixture was stirred at room temperature for $30 \mathrm{~min}$ before benzyl bromide $(4.17 \mathrm{~g}$, $24.4 \mathrm{mmol}$ ) was added dropwise. The reaction was monitored by TLC until the starting material disappeared. The reaction mixture was washed with brine, and the organic layer was dried over anhydrous $\mathrm{Na}_{2} \mathrm{SO}_{4}$. After removal of the solvent, the residue was purified by column chromatography using ethyl acetate/cycle hexane (1:2) as an eluent to obtain product 9 as a pale-yellow oil $(3.4 \mathrm{~g}, 62 \%) .{ }^{1} \mathrm{H}$ NMR $\left(\mathrm{CDCl}_{3}, 400 \mathrm{MHz}\right) \delta 1.14\left(\mathrm{~d}, J=6.6 \mathrm{~Hz}, 3 \mathrm{H}, \mathrm{CH}_{3}\right), 4.19-4.28(\mathrm{~m}$, $\left.2 \mathrm{H}, \mathrm{CH}_{2}\right), 4.67(\mathrm{q}, J=6.6 \mathrm{~Hz}, 1 \mathrm{H}, \mathrm{CH}), 5.19\left(\mathrm{~s}, 2 \mathrm{H}, \mathrm{CH}_{2}\right), 6.40(\mathrm{~d}, J$ $=5.6 \mathrm{~Hz}, 1 \mathrm{H}, \mathrm{C} 5-\mathrm{H}$ in pyridinone $), 7.24-7.33(\mathrm{~m}, 10 \mathrm{H}, \mathrm{Ph}), 7.71(\mathrm{~d}$, $J=5.6 \mathrm{~Hz}, 1 \mathrm{H}, \mathrm{C} 6-\mathrm{H}$ in pyridinone). ESI-MS: $m / z 337\left([\mathrm{M}+\mathrm{H}]^{+}\right)$.

3-(Benzyloxy)-2-(1-(benzyloxy)ethyl)-1-(6-hydroxyhexyl)pyridin$4(1 \mathrm{H})$-one $(10)$. The synthetic procedure was similar to that adopted for the preparation of 4 . Yield: $66 \% .{ }^{1} \mathrm{H}$ NMR $\left(\mathrm{CDCl}_{3}, 400 \mathrm{MHz}\right) \delta$ $1.14-1.29\left(\mathrm{~m}, 4 \mathrm{H}, \mathrm{CH}_{2}\right), 1.22\left(\mathrm{~d}, J=7.0 \mathrm{~Hz}, 3 \mathrm{H}, \mathrm{CH}_{3}\right), 1.44(\mathrm{~m}, 2 \mathrm{H}$, $\left.\mathrm{CH}_{2}\right), 1.62\left(\mathrm{~m}, 2 \mathrm{H}, \mathrm{CH}_{2}\right), 3.56\left(\mathrm{t}, J=6.5 \mathrm{~Hz}, 2 \mathrm{H}, \mathrm{CH}_{2}\right), 3.98$ and 4.10 $\left(\mathrm{m}, 2 \mathrm{H}, \mathrm{CH}_{2}\right), 4.16\left(\mathrm{~s}, 2 \mathrm{H}, \mathrm{CH}_{2}\right), 5.26\left(\mathrm{~s}, 2 \mathrm{H}, \mathrm{CH}_{2}\right), 6.48(\mathrm{~d}, J=7.5$ $\mathrm{Hz}, 1 \mathrm{H}, \mathrm{C} 5-\mathrm{H}$ in pyridinone), $7.21(\mathrm{~m}, 3 \mathrm{H}, \mathrm{Ph}$ and buried $\mathrm{C} 6-\mathrm{H}$ in pyridinone), 7.28-7.34 (m, 8H, Ph). ESI-MS: $m / z 436\left([\mathrm{M}+\mathrm{H}]^{+}\right)$, $458\left([\mathrm{M}+\mathrm{Na}]^{+}\right)$.

6-(3-(Benzyloxy)-2-(1-(benzyloxy)ethyl)-4-oxopyridin-1(4H)-yl)hexyl-5-((benzyloxycarbonyl)amino)-4-oxopentanoate (11). ${ }^{1} \mathrm{H}$ $\mathrm{NMR}\left(\mathrm{CDCl}_{3}, 270 \mathrm{MHz}\right) \delta 1.22\left(\mathrm{~m}, 7 \mathrm{H}, 2 \mathrm{CH}_{2}\right.$ and $\left.\mathrm{CH}_{3}\right), 1.44-$ $1.59\left(\mathrm{~m}, 4 \mathrm{H}, 2 \mathrm{CH}_{2}\right), 2.58-2.69\left(\mathrm{~m}, 4 \mathrm{H}, 2 \mathrm{CH}_{2}\right), 3.93-4.14(\mathrm{~m}, 7 \mathrm{H}$, $3 \mathrm{CH}_{2}$ and $\left.\mathrm{CH}\right), 5.09\left(\mathrm{~s}, 2 \mathrm{H}, \mathrm{CH}_{2}\right), 5.22\left(\mathrm{~s}, 4 \mathrm{H}, 2 \mathrm{CH}_{2}\right), 5.63(\mathrm{~s}, 1 \mathrm{H}$, $\mathrm{NH}), 6.46(\mathrm{~d}, J=7.4 \mathrm{~Hz}, 1 \mathrm{H}, \mathrm{C} 5-\mathrm{H}$ in pyridinone $), 7.38-7.47(\mathrm{~m}$, $15 \mathrm{H}, 3 \mathrm{Ph}), 8.82$ (d, $J=7.4 \mathrm{~Hz}, 1 \mathrm{H}, \mathrm{C} 6-\mathrm{H}$ in pyridinone). ${ }^{13} \mathrm{C}$ NMR: $\delta$ 20.4, 25.6, 26.2, 27.7, 27.8, 28.4, 31.7, 34.5, 50.7, 52.3, 64.6, 66.7, 67.0, $69.7,71.2,74.7,117.9,127.6,128.2,128.3,128.5,128.5,129.4,137.5$, 138.5, 140.0, 144.5, 146.0, 156.3, 172.5, 173.8, 206.7. ESI-MS: $\mathrm{m} / z$ $683\left([\mathrm{M}+\mathrm{H}]^{+}\right), 705\left([\mathrm{M}+\mathrm{Na}]^{+}\right)$.
5-((6-(2-Ethyl-3-hydroxy-4-oxopyridin-1(4H)-yl)hexyl)oxy)-2,5-dioxopentan-1-aminium Chloride (12). The product was isolated as thick oil, yield $35 \%$, HPLC-DAD ( $R_{\mathrm{t}}: 3.5 \mathrm{~min}$; purity $\left.96.5 \%\right) .{ }^{1} \mathrm{H}$ $\operatorname{NMR}\left(\mathrm{CD}_{3} \mathrm{OH}, 270 \mathrm{MHz}\right) \delta 1.20-1.44\left(\mathrm{~m}, 7 \mathrm{H}, 2 \mathrm{CH}_{2}\right.$ and $\left.\mathrm{CH}_{3}\right)$, 1.93-2.06 (m, 4H, $\left.\mathrm{CH}_{2}\right), 2.66\left(\mathrm{~m}, 2 \mathrm{H}, \mathrm{CH}_{2}\right), 2.81\left(\mathrm{~m}, 2 \mathrm{H}, \mathrm{CH}_{2}\right)$, $3.57\left(\mathrm{~m}, 2 \mathrm{H}, \mathrm{CH}_{2}\right), 4.09\left(\mathrm{~m}, 4 \mathrm{H}, 2 \mathrm{CH}_{2}\right), 5.67(\mathrm{~m}, 1 \mathrm{H}, \mathrm{CH}), 7.19(\mathrm{~d}, J$ $=6.4 \mathrm{~Hz}, 1 \mathrm{H}, \mathrm{C} 5-\mathrm{H}$ in pyridinon), $8.21(\mathrm{~d}, J=6.7 \mathrm{~Hz}, 1 \mathrm{H}, \mathrm{C} 6-\mathrm{H}$ in pyridinon). ${ }^{13} \mathrm{C}$ NMR: $\delta 13.9,19.4,25.4,26.8,27.1,34.23,36.2,50.3$, 52.6, 64.4, 72.2, 116.8, 126.2, 137.4, 141.5, 156.2, 173.1, 201.2. ESIMS: $369.2\left([\mathrm{M}+\mathrm{H}]^{+}\right), 391.2\left([\mathrm{M}+\mathrm{Na}]^{+}\right)$. HRMS: calcd for $\mathrm{C}_{18} \mathrm{H}_{29} \mathrm{~N}_{2} \mathrm{O}_{6}, 369.2026\left([\mathrm{M}+\mathrm{H}]^{+}\right)$; found, 369.2019.

4.2.8. Synthesis of ALA-HPO Conjugate 18. 3-(Benzyloxy)-Nmethyl-4-oxo-4H-pyran-2-carboxamide (15). A solution of 3(benzyloxy)-4-oxo-4H-pyran-2-carboxylic acid 14 (0.94g, $3.82 \mathrm{mmol})$ and $N$-hydroxysuccimide $(0.485 \mathrm{~g}, 4.2 \mathrm{mmol})$ in tetrahydrogenfuran $(20 \mathrm{~mL})$ was stirred at room temperature for $30 \mathrm{~min}$. DCC $(0.866 \mathrm{~g}$, $4.2 \mathrm{mmol}$ ) was added, and the stirring was continued for $5 \mathrm{~h}$. Methylamine ( $2 \mathrm{M}$ in THF, $4.58 \mathrm{mmol}$ ) was added, and the solution was stirred at room temperature overnight. After filtration, the filtrate was concentrated and the residue was purified by column chromatography using ethyl acetate/methanol (9:1) as an eluent to obtain product $(0.85 \mathrm{~g}, 86 \%) .{ }^{1} \mathrm{H}$ NMR $\left(\mathrm{CDCl}_{3}, 400 \mathrm{MHz}\right) \delta 2.78(\mathrm{~d}$, $\left.J=5.0 \mathrm{~Hz}, 3 \mathrm{H}, \mathrm{CH}_{3}\right), 5.39\left(\mathrm{~s}, 2 \mathrm{H}, \mathrm{CH}_{2}\right), 6.49(\mathrm{~d}, J=5.6 \mathrm{~Hz}, 1 \mathrm{H}, \mathrm{C} 5-$ $\mathrm{H}$ in pyridinone), $7.40(\mathrm{~m}, 5 \mathrm{H}, \mathrm{Ph}), 7.70(\mathrm{br}, 1 \mathrm{H}, \mathrm{NH}), 7.84(\mathrm{~d}, J=$ $5.6 \mathrm{~Hz}, 1 \mathrm{H}, \mathrm{C} 6-\mathrm{H}$ in pyridinone). ESI-MS: $m / z 260\left([\mathrm{M}+\mathrm{H}]^{+}\right)$.

3-(Benzyloxy)-1-(6-hydroxyhexyl)-N-methyl-4-oxo-1,4-dihydropyridine-2-carboxamide (16). ${ }^{1} \mathrm{H} \mathrm{NMR}\left(\mathrm{CDCl}_{3}, 400 \mathrm{MHz}\right) \delta 1.30-$ $1.42\left(\mathrm{~m}, 4 \mathrm{H}, \mathrm{CH}_{2}\right), 1.55\left(\mathrm{~m}, 2 \mathrm{H}, \mathrm{CH}_{2}\right), 1.76\left(\mathrm{~m}, 2 \mathrm{H}, \mathrm{CH}_{2}\right), 2.73(\mathrm{~d}, J$ $\left.=4.9 \mathrm{~Hz}, 3 \mathrm{H}, \mathrm{CH}_{3}\right), 3.62\left(\mathrm{t}, J=6.3 \mathrm{~Hz}, 2 \mathrm{H}, \mathrm{CH}_{2}\right), 3.83(\mathrm{t}, J=7.5 \mathrm{~Hz}$, $\left.2 \mathrm{H}, \mathrm{CH}_{2}\right), 5.09\left(\mathrm{~s}, 2 \mathrm{H}, \mathrm{CH}_{2}\right), 6.30(\mathrm{~d}, J=7.4 \mathrm{~Hz}, 1 \mathrm{H}, \mathrm{C} 5-\mathrm{H}$ in pyridinone), 7.13 (d, $J=7.4 \mathrm{~Hz}, 1 \mathrm{H}, \mathrm{C} 6-\mathrm{H}$ in pyridinone), 7.31 (m, $5 \mathrm{H}, \mathrm{Ph}), 7.43(\mathrm{~m}, 1 \mathrm{H}, \mathrm{NH})$. ESI-MS: $m / z 359\left([\mathrm{M}+\mathrm{H}]^{+}\right), 381([\mathrm{M}$ $\left.+\mathrm{Na}]^{+}\right)$.

6-(3-(Benzyloxy)-2-(methylcarbamoyl)-4-oxopyridin-1(4H)-yl)hexyl 5-(((benzyloxy)carbonyl)amino)-4-oxopentanoate (17). The product was isolated as yellow paste, yield $80 \% .{ }^{1} \mathrm{H} \mathrm{NMR}\left(\mathrm{CDCl}_{3}, 270\right.$ $\mathrm{MHz}) \delta 1.30\left(\mathrm{~m}, 4 \mathrm{H}, 2 \mathrm{CH}_{2}\right), 1.57\left(\mathrm{~m}, 2 \mathrm{H}, \mathrm{CH}_{2}\right), 1.74\left(\mathrm{~m}, 2 \mathrm{H}, \mathrm{CH}_{2}\right)$, $2.60-2.68\left(\mathrm{~m}, 4 \mathrm{H}, 2 \mathrm{CH}_{2}\right), 2.70\left(\mathrm{~d}, J=2.9 \mathrm{~Hz}, 3 \mathrm{H}, \mathrm{CH}_{3}\right), 2.76(\mathrm{~m}$, $\left.2 \mathrm{H}, \mathrm{CH}_{2}\right) 4.02\left(\mathrm{~m}, 4 \mathrm{H}, 2 \mathrm{CH}_{2}\right), 4.98\left(\mathrm{~s}, 2 \mathrm{H}, \mathrm{CH}_{2}\right), 5.06\left(\mathrm{~s}, 2 \mathrm{H}, \mathrm{CH}_{2}\right)$, $5.71(\mathrm{br}, 1 \mathrm{H}, \mathrm{NH}), 6.20(\mathrm{~d}, J=7.4,1 \mathrm{H}, \mathrm{C} 5-\mathrm{H}$ in pyridinone), 7.25 (d, $J=7.4 \mathrm{~Hz}$, C6-H in pyridinone), 7.27-7.32 (m, 10H, 2Ph), 8.01 (br, $\mathrm{H}, \mathrm{NH}) .{ }^{13} \mathrm{C}$ NMR: $\delta 25.1,25.4,26.0,26.3,27.9,28.4,31.7,34.5,50.1$, 54.9, 64.6, 67.7, 74.2, 118.0, 128.0, 128.1, 128.3, 128.6, 134.9, 136.8, $138.5,140.1,145.8,156.2,161.6,172.5,173.8,204.3$. ESI-MS: $\mathrm{m} / \mathrm{z}$ $606\left([\mathrm{M}+\mathrm{H}]^{+}\right), 628\left([\mathrm{M}+\mathrm{Na}]^{+}\right)$.

5-((6-(3-Hydroxy-2-(methylcarbamoyl)-4-oxopyridin-1(4H)-yl)hexyl)oxy)-2,5-dioxopentan-1-aminium Chloride (18). The product was isolated as thick oil, yield $37 \%$, HPLC-DAD $\left(R_{\mathrm{t}}: 3.4 \mathrm{~min}\right.$; purity 97.0\%). ${ }^{1} \mathrm{H}$ NMR $\left(\mathrm{CD}_{3} \mathrm{OH}, 270 \mathrm{MHz}\right) \delta 1.52\left(\mathrm{~m}, 4 \mathrm{H}, 2 \mathrm{CH}_{2}\right), 1.64$ $\left(\mathrm{m}, 2 \mathrm{H}, \mathrm{CH}_{2}\right), 2.07\left(\mathrm{~m}, 2 \mathrm{H}, \mathrm{CH}_{2}\right), 2.67\left(\mathrm{~m}, 2 \mathrm{H}, \mathrm{CH}_{2}\right), 2.83(\mathrm{~m}, 2 \mathrm{H}$, $\left.\mathrm{CH}_{2}\right), 3.28\left(\mathrm{~s}, 3 \mathrm{H}, \mathrm{CH}_{3}\right), 4.02-4.07\left(\mathrm{~m}, 4 \mathrm{H}, 2 \mathrm{CH}_{2}\right), 4.35(\mathrm{~m}, 2 \mathrm{H}$, $\left.\mathrm{CH}_{2}\right), 7.26(\mathrm{~d}, J=6.4 \mathrm{~Hz}, 1 \mathrm{H}, \mathrm{C} 5-\mathrm{H}$ in pyridinone $), 8.30(\mathrm{~d}, J=6.7$ $\mathrm{Hz}, 1 \mathrm{H}, \mathrm{C} 6-\mathrm{H}$ in pyridinone). ${ }^{13} \mathrm{C}$ NMR: $\delta 25.0,25.5,26.1,27.2,27.9$, 28.1, 34.0, 50.1, 59.2, 64.6, 112.0, 136.5, 138.7, 143.0, 162.5, 158.2, 172.8, 201.8. ESI-MS: $m / z 382.2\left([\mathrm{M}+\mathrm{H}]^{+}\right), 404.4\left([\mathrm{M}+\mathrm{Na}]^{+}\right)$. HRMS: calcd for $\mathrm{C}_{18} \mathrm{H}_{28} \mathrm{~N}_{3} \mathrm{O}_{6}, 382.1978\left([\mathrm{M}+\mathrm{H}]^{+}\right)$; found, 382.1966.

4.2.9. Synthesis of ALA-HPO Conjugate 23. 2-(2-(2Aminoethoxy)ethoxy)ethanol (20). The synthetic procedure was similar to that of $3 .{ }^{1} \mathrm{H}$ NMR $\left(\mathrm{CDCl}_{3}, 400 \mathrm{MHz}\right) \delta 2.19(\mathrm{br}, 2 \mathrm{H}$, $\left.\mathrm{NH}_{2}\right), 2.88\left(\mathrm{t}, J=5.1 \mathrm{~Hz}, 2 \mathrm{H}, \mathrm{CH}_{2}\right), 3.55\left(\mathrm{t}, J=5.1 \mathrm{~Hz}, 2 \mathrm{H}, \mathrm{CH}_{2}\right)$, 3.60-3.74 (m, 8H, $\left.\mathrm{CH}_{2}\right)$. ESI-MS: $m / z 150\left([\mathrm{M}+\mathrm{H}]^{+}\right)$.

1-(2-(2-Hydroxyethoxy)ethyl)-3-(benzyloxy)-2-ethylpyridin-4(1H)one (21). The synthetic procedure was similar to that of $4 .{ }^{1} \mathrm{H}$ NMR $\left(\mathrm{CDCl}_{3}, 400 \mathrm{MHz}\right) \delta 1.00\left(\mathrm{t}, J=7.5 \mathrm{~Hz}, 3 \mathrm{H}, \mathrm{CH}_{3}\right), 2.63(\mathrm{q}, J=7.5$ $\left.\mathrm{Hz}, 2 \mathrm{H}, \mathrm{CH}_{2}\right), 3.54\left(\mathrm{~m}, 6 \mathrm{H}, \mathrm{CH}_{2}\right), 3.66-3.73\left(\mathrm{~m}, 4 \mathrm{H}, \mathrm{CH}_{2}\right), 3.98(\mathrm{t}, J$ $\left.=5.2 \mathrm{~Hz}, 2 \mathrm{H}, \mathrm{CH}_{2}\right), 5.25\left(\mathrm{~s}, 2 \mathrm{H}, \mathrm{CH}_{2}\right), 6.43(\mathrm{~d}, J=7.6 \mathrm{~Hz}, 1 \mathrm{H}, \mathrm{C} 5-\mathrm{H}$ in pyridinone $), 7.28-7.35(\mathrm{~m}, 4 \mathrm{H}, \mathrm{Ph}$ and buried $\mathrm{C} 6-\mathrm{H}$ in pyridinone), $7.44(\mathrm{~m}, 2 \mathrm{H}, \mathrm{Ph})$. ESI-MS: $m / z 362\left([\mathrm{M}+\mathrm{H}]^{+}\right), 384$ $\left([\mathrm{M}+\mathrm{Na}]^{+}\right)$. 
2-(2-(2-(3-(Benzyloxy)-2-ethyl-4-oxopyridin-1(4H)-yl)ethoxy)ethoxy)ethyl-5-(((benzyloxy)carbonyl)amino)-4-oxopentanoate (22). The product was isolated as thick oil, yield $70 \% .{ }^{1} \mathrm{H}$ NMR $\left(\mathrm{CDCl}_{3}, 270 \mathrm{MHz}\right) \delta 0.98\left(\mathrm{t}, 3 \mathrm{H}, \mathrm{CH}_{3}\right), 2.59-2.61\left(\mathrm{~m}, 6 \mathrm{H}, 3 \mathrm{CH}_{2}\right)$, 3.47-3.73 (m, 8H, 4CH $), 3.90\left(\mathrm{~m}, 2 \mathrm{H}, \mathrm{CH}_{2}\right), 4.04\left(\mathrm{~s}, 2 \mathrm{H}, \mathrm{CH}_{2}\right)$, $4.30\left(\mathrm{~m}, 2 \mathrm{H}, \mathrm{CH}_{2}\right), 5.05\left(\mathrm{~s}, 2 \mathrm{H}, \mathrm{CH}_{2}\right), 5.19\left(\mathrm{~s}, 2 \mathrm{H}, \mathrm{CH}_{2}\right), 5.90(\mathrm{br}, \mathrm{H}$, $\mathrm{NH}), 6.35(\mathrm{~d}, 1 \mathrm{H}, J=7.4 \mathrm{~Hz}, 1 \mathrm{H}, \mathrm{C} 5-\mathrm{H}$ in pyridinone), 7.23-7.27 $(\mathrm{m}, 10 \mathrm{H}, 2 \mathrm{Ph}), 7.38$ (d, $J=7.4 \mathrm{~Hz}, 1 \mathrm{H}, \mathrm{C} 6-\mathrm{H}$ pyridinone). ${ }^{13} \mathrm{C}$ NMR: $\delta$ 13.2, 19.5, 27.5, 27.9, 34.2, 50.7, 52.6, 63.8, 70.6, 70.9, 71.3, 72.9, $117.1,128.3,128.7,136.5,137.9,138.0,139.4,145.7,146.0,156.5$, 172.4, 173.7, 204.6. ESI-MS: $m / z 609\left([\mathrm{M}+\mathrm{H}]^{+}\right), 631\left([\mathrm{M}+\mathrm{Na}]^{+}\right)$. 5-(2-(2-(2-(2-Ethyl-3-hydroxy-4-oxopyridin-1(4H)-yl)ethoxy)ethoxy)ethoxy)-2,5-dioxopentan-1-aminium Chloride (23). The product was isolated as thick oil, yield 37\%, HPLC-DAD $\left(R_{\mathrm{t}}: 2.8\right.$ min; purity 95.8\%). ${ }^{1} \mathrm{H}$ NMR $\left(\mathrm{CD}_{3} \mathrm{OH}, 270 \mathrm{MHz}\right) \delta 1.17(\mathrm{t}, J=7.1$ $\left.\mathrm{Hz}, 3 \mathrm{H}, \mathrm{CH}_{3}\right), 2.56\left(\mathrm{~m}, 2 \mathrm{H}, \mathrm{CH}_{2}\right), 2.73\left(\mathrm{~m}, 2 \mathrm{H}, \mathrm{CH}_{2}\right), 3.01(\mathrm{q}, J=5.4$ $\left.\mathrm{Hz}, 2 \mathrm{H}, \mathrm{CH}_{2}\right), 3.21\left(\mathrm{~m}, 2 \mathrm{H}, \mathrm{CH}_{2}\right), 3.47\left(\mathrm{~m}, 6 \mathrm{H}, 3 \mathrm{CH}_{2}\right), 3.54(\mathrm{~m}, 2 \mathrm{H}$, $\left.\mathrm{CH}_{2}\right), 3.90\left(\mathrm{~s}, 2 \mathrm{H}, \mathrm{CH}_{2}\right), 4.65\left(\mathrm{~m}, 2 \mathrm{H}, \mathrm{CH}_{2}\right), 7.07(\mathrm{~d}, J=6.4 \mathrm{~Hz}, 1 \mathrm{H}$, C5- $\mathrm{H}$ in pyridinon $), 8.08(\mathrm{~d}, J=6.7 \mathrm{~Hz}, 1 \mathrm{H}, \mathrm{C} 6-\mathrm{H}$ in pyridinone $) .{ }^{13} \mathrm{C}$ NMR: $\delta$ 13.9, 19.4, 25.4, 27.1, 34.23, 36.2, 26.8, 50.3, 52.6, 64.4, 72.2, $116.8126 .2,137.4,141.5 .4,156.2,173.1,204.2$. ESI-MS: $m / z 385$ ([M $\left.+\mathrm{H}]^{+}\right), 407\left([\mathrm{M}+\mathrm{Na}]^{+}\right)$. HRMS: calcd for $\mathrm{C}_{18} \mathrm{H}_{29} \mathrm{~N}_{2} \mathrm{O}_{7}, 385.1975$ $\left([\mathrm{M}+\mathrm{H}]^{+}\right)$; found, 385.1968 .

4.3. Cell Culture. The human breast adenocarcinoma cell line MCF-7, doxorubicin-resistant counterpart MCF-7R line (donated by Dr Marilena Loizidou, UCL), and the human oral epidermal carcinoma KB cell line purchased from ATCC were employed for this study. Both MCF-7 and MCF-7R cell lines were cultured in DMEM-F12 containing L-glutamine $(20 \mu \mathrm{M})$ and phenol red. $\mathrm{KB}$ cells were cultured in Eagle's Minimum Essential Medium (EMEM) containing L-glutamine $(20 \mu \mathrm{M})$, phenol red, and nonessential amino acid $(5 \mathrm{~mL})$. The media for all cell lines was supplemented with gentamicin (500 units/mL; Life Technologies) and $10 \%$ fetal calf serum, and it was standardized to give an iron concentration between 450 and $600 \mu \mathrm{g} / 100 \mathrm{~g}$ in order to reach the physiological iron levels in biological systems. ${ }^{30}$ The cells were grown as monolayers in sterile, vented-capped, angle-necked cell culture flasks (Corning) and were maintained at $37{ }^{\circ} \mathrm{C}$ in a humidified $5 \% \mathrm{CO}_{2}$ incubator (IR Autoflow Water-Jacketed Incubator; Jencons Nuaire) until confluent.

4.3.1. Fluorescence Pharmacokinetics and Mechanistic Study. Cells were seeded into $\gamma$-sterilized 96-well plates (Orange Scientific, Triple Red Laboratory Technologies) at a density of $\sim 5 \times 10^{4}$ per well for $48 \mathrm{~h}$. The culture medium was removed, and the cells were washed with PBS. The cells were incubated with freshly prepared solutions of ALA and ALA-HPOs derivatives: $100 \mu \mathrm{L}$ serum-free medium containing varying prodrugs concentrations was added to a designated series of wells. Each plate contained wells with cells without prodrug as control for subtracting the natural PpIX fluorescence reading. PpIX fluorescence induced by ALA and ALA-HPOs derivatives was measured from each well with a PerkinElmer LS 50B fluorescence spectrometer coupled to an automated plate reader (PerkinElmer) using $405 \mathrm{~nm}$ excitation and $635 \mathrm{~nm}$ emission wavelengths with slit widths set to $10 \mathrm{~nm}$ and the internal $515 \mathrm{~nm}$ long-pass filter used on the emission side. The spectral scans were recorded between 600 and $750 \mathrm{~nm}$, discriminating PpIX from other porphyrins, should any be present. The mean fluorescence intensity (expressed in arbitrary units) was calculated after subtraction the control values. Time course measurements for PpIX fluorescence intensities were recorded with ALA or ALA-HPOs over periods of 2, 4, 6, and $24 \mathrm{~h}$ with concentration varied between 1 and $100 \mu \mathrm{M}$.

Study on Dependence of ALA Transport on Temperature. Temperature dependent study was conducted for cellular uptake of prodrugs. MCF-7R and KB cells were seeded in two 96-well $\gamma$ irradiated plates, incubated for $48 \mathrm{~h}$, and washed with PBS. ALA and ALA-HPOs prodrugs $(500 \mu \mathrm{M})$ in clear medium were added at 100 $\mu \mathrm{L} /$ well, and the plates were wrapped in foil. One plate was incubated at $37{ }^{\circ} \mathrm{C}$ and the other at $4{ }^{\circ} \mathrm{C}$ for $1 \mathrm{~h}$. The prodrugs were then removed, cells were rinsed in PBS, and $100 \mu \mathrm{L}$ of clear medium was added to each well. The plates were both incubated at $37^{\circ} \mathrm{C}$ for $4 \mathrm{~h}$ to allow the ALA already taken up by the cells to be converted to PpIX.
The amount of PpIX produced by the cells in the different conditions was evaluated as described above.

4.3.2. Photodynamic Treatment. Cells were seeded into 96-well plates at a density of $\sim 5 \times 10^{4}$ per well. Following incubation for $48 \mathrm{~h}$, the cells were washed with PBS and $100 \mu \mathrm{L}$ solutions containing each compound at varying concentrations (between 1 and $100 \mu \mathrm{M}$ ) were added to their designated wells for set incubation periods. Each well plate contained three control wells without the compound and the compound at five different concentrations in triplicate. The plates were irradiated with a fluence of $2.5 \mathrm{~J} / \mathrm{cm}^{2}$ using a LumiSource lamp (PCI Biotech), which emits a uniform field of low-power blue light over an area of $14 \mathrm{~cm} \times 32 \mathrm{~cm}$. Peak output was $\sim 420 \mathrm{~nm}$, which overlapped with the PpIX Soret band. Immediately following irradiation, the medium was replaced and cells were incubated for further $18 \mathrm{~h}$. Cell cytotoxicity at $24 \mathrm{~h}$ after treatment was determined using the 3-(4, 5dimethylthiazol-2-yl)-2,5-diphenyltetrazolium bromide (MTT) assay: cells were incubated with medium containing MTT $(1 \mathrm{mg} / \mathrm{mL}$ dissolved in full DMEM-12 for MCF-7 and MCF-7R, EMEM for KB) for $2 \mathrm{~h}$. The insoluble end product (formazan derivatives) was dissolved in $100 \mu \mathrm{L}$ of DMSO after removing the medium. Absorbance was quantified at $570 \mathrm{~nm}$ using a 96-well plate reader (ELX800, BioTek Instruments). The mean cell survival was calculated for each prodrug at every concentration tested and expressed as a percentage of control cell survival values. Control wells contained cells without compounds and allocated in the same plate with the other compounds that were irradiated for phototoxicity experiments. For determination of "dark" toxicity of the compounds, well plates were prepared in the same manner as above but without irradiation.

4.3.3. Determination of Intracellular PpIX Content. Cells were seeded into $100 \mathrm{~mm}$ Petri dishes at a density of $5 \times 10^{4}$ cells per well for $48 \mathrm{~h}$ at $37{ }^{\circ} \mathrm{C}$. The culture medium was removed, and the cells were washed with PBS. The cells were then incubated with the $100 \mu \mathrm{L}$ of ALA or the selected ALA-HPO prodrugs for $4 \mathrm{~h}$ and then washed twice with PBS. CelLytic (Sigma-Aldrich) $(1 \mathrm{~mL})$ was added and incubated for $15 \mathrm{~min}$ at room temperature, and the cells were scraped and collected in cryostat vials. Cell extracts were centrifuged at $1800 \mathrm{~g}$ for $10 \mathrm{~min}$ to remove the cell debris, and the supernatant containing the PpIX was collected. The content of PpIX in the cell lysates was determined by a fluorescence plate reader (PerkinElmer) in 96-well plates, with excitation wavelength at $405 \mathrm{~nm}$ and emission at wavelength at $635 \mathrm{~nm}$ as reported above. The protein content of the cells was determined using a bicinchoninic acid protein determination kit (Sigma-Aldrich). We found that the final solution of the derivatized products after acidic hydrolysis and derivatization was inhomogeneous; it was causing inconsistent result with HPLC analysis. Therefore, the ratio of acetylacetone solution was modified to increase the percentage of ethanol. The recovery of intracellular accumulation of ALA from ALA-HPOs was similar to ALA quantities after acidic hydrolysis for $1 \mathrm{~h}$ of incubation in KB and MCF-7R cell lines. Therefore, ester hydrolysis of the conjugates takes place rapidly and efficiently inside the cells. For all $6 \times 24$-well test plates, the last three wells contained control cells not incubated with any compounds (blank controls). The PpIX fluorescence measurements from these wells were used to subtract the natural cellular PpIX autofluorescence from all the other measurements made from the same plate.

4.3.4. Intracellular ALA Determination. Sample Derivatization and Analysis Procedures. Stock solutions of ALA and ALA-HPO conjugates in deionized water were prepared and stored at $-20{ }^{\circ} \mathrm{C}$. Working solutions were prepared daily by dilution of the stock solutions in media without phenol red or serum. Calibration samples were prepared by spiking blank cell lysate with the appropriate working solution. The acetylacetone reagent was prepared by mixing absolute ethanol, water, and acetylacetone in a 45/40/15 volumetric ratio. Formaldehyde $10 \%$ was obtained by dilution of the commercially available $37 \%(\mathrm{v} / \mathrm{v})$ aqueous solution in water. The solutions were stored at $4{ }^{\circ} \mathrm{C}$. The derivatization reactions were performed in a parallel synthesizer (Acteviotech) equipped with a 16-position reaction blocks. For the determination of ALA, the calibration samples were prepared by spiking $90 \mu \mathrm{L}$ of cell lysate with $10 \mu \mathrm{L}$ of the appropriate working solution. For the determination of ALA esters, $350 \mu \mathrm{L}$ of cell 
lysate was spiked with $50 \mu \mathrm{L}$ of the appropriate working solution. Then $200 \mu \mathrm{L}$ of such a mixture was diluted to $2 \mathrm{~mL}$ with $0.01 \mathrm{M} \mathrm{HCl}$ in a $16 \mathrm{~mm}$ parallel synthesizer reaction tube. The tubes were transferred into the Greenhouse reactor preheated at $100{ }^{\circ} \mathrm{C}$, refluxed for $3 \mathrm{~h}$ under stirring, and then cooled in an ice-bath. In an Acteviotech reaction tube equipped with a magnetic stirrer, $50 \mu \mathrm{L}$ of calibration sample was added to $3500 \mu \mathrm{L}$ of acetylacetone reagent and $450 \mu \mathrm{L}$ of $10 \%$ formaldehyde solution. The tubes were placed in the parallel synthesizer reactor preheated at $100{ }^{\circ} \mathrm{C}$ and stirred for $10 \mathrm{~min}$. The reactor chamber was wrapped with foil in order to protect the tubes with the reaction mixture from light. The samples were then cooled in an ice-bath in the dark for $2 \mathrm{~h}$, transferred into HPLC vials, and kept in the autosampler at room temperature until the analysis was performed.

HPLC Fluorescence Analysis. HPLC analysis were performed on a Agilent system (Life Sciences \& Chemical Analysis Group UK), following the published protocol with some modification. ${ }^{49}$ The system consisted of a G1311A QuatPump fitted with an internal vacuum degasser, a WPS-300SL analytical autosampler equipped H3BDSC10-H column compartment, and a G132A FLD fluorescence detector. The separations were performed on a Gemini $5 \mu \mathrm{C} 18$ H3BDSC10-H column, $100 \mathrm{~mm} \times 2.1 \mathrm{~mm}$ (Phenomenex, UK), equipped with a Security Guard C18 (ODS) $4 \mathrm{~mm} \times 2.1 \mathrm{~mm} \mathrm{ID}$ guard column (Phenomenex, UK) at $35 \pm 0.1{ }^{\circ} \mathrm{C}$. The mobile phase consisted of $0.05 \%$ formic acid in water (solvent A) and $0.05 \%$ formic acid in methanol (solvent B). The composition of the mobile phase was as follows: $5.0-0.0 \mathrm{~min}$ at $40 \%$ solvent $\mathrm{B}, 0.0-7.0 \mathrm{~min}$ at $40 \%$ solvent $B, 7.0-7.1 \mathrm{~min} 40-95 \%$ solvent $\mathrm{B}, 7.1-10.0 \mathrm{~min}$ at $95 \%$ solvent $\mathrm{B}, 10.0-10.1 \mathrm{~min} 95-40 \%$ solvent $\mathrm{B}$. The flow rate was 0.5 $\mathrm{mL} / \mathrm{min} . \lambda_{\text {exc }}=370 \mathrm{~nm}$ and $\lambda_{\text {em }}=460 \mathrm{~nm}$ were used for the detection. For the low concentration range, $20 \mu \mathrm{L}$ of sample were injected and the fluorescence detector was set on high sensitivity. For the high concentration range, $10 \mu \mathrm{L}$ were injected and the detector was set on medium sensitivity. The peak corresponding to 1 eluted at $4.72 \mathrm{~min}$. The total time required for the analysis was $12.1 \mathrm{~min}$.

4.3.5. Statistical Analysis. All data points and bars in the figures represent average values calculated from test solution concentrations being carried out in triplicate. The results were tabulated or graphically displayed with error bars representing the standard deviation (SD) of the mean. Data were analyzed using the unpaired Student's $t$-test, and results with $P<0.05$ were considered significant.

\section{ASSOCIATED CONTENT}

\section{(S Supporting Information}

The Supporting Information is available free of charge on the ACS Publications website at DOI: 10.1021/acs.jmedchem.7b00346.

Molecular formula strings (CSV)

\section{AUTHOR INFORMATION}

\section{Corresponding Author}

*Phone: +86 571 28008976. E-mail: taozhou@zjgsu.edu.cn. ORCID $\odot$

Tao Zhou: 0000-0003-4510-3639

\section{Notes}

The authors declare no competing financial interest.

\section{ACKNOWLEDGMENTS}

We thank EPSRC (EP/G005087, EP/G004986, EP/G004382), Zhejiang Provincial Natural Science Foundation of China (LY12B02014), and Science Technology Department of Zhejiang Province of China (no. 2013C24006) for the financial support.

\section{ABBREVIATIONS USED}

ALA, 5-aminolaevulinic acid; HPO, 3-hydroxypyridinone; $\mathrm{DAD}$, diode array detector; DCC, dicyclohexylcarboimide; DFO, desferrioxamine; DMAP, 4-dimethylpyridylamine; $\mathrm{N}-\mathrm{Z}$ ALA, N-benzyloxycarbonyl-5-aminolevulinic acid; DIPAD, diisopropyl azodicarboxylate; MTT, 3-(4,5-dimethylthiazol-2yl)-2,5- diphenyltetrazolium bromide; PBS, phosphate buffered saline; PDT, photodynamic therapy; PpIX, protoporphyrin IX; EDTA, ethylenediamine tetraacetic acid

\section{REFERENCES}

(1) Juzeniene, A.; Peng, Q.; Moan, J. Milestones in the development of photodynamic therapy and fluorescence diagnosis. Photochem. Photobiol. Sci. 2007, 6, 1234-1245.

(2) Vrouenraets, M. B.; Visser, G. W.; Snow, G. B.; van Dongen, G. A. Basic principles, applications in oncology and improved selectivity of photodynamic therapy. Anticancer Res. 2003, 23, 505-522.

(3) De Rosa, F. S.; Bentley, M. V. Photodynamic therapy of skin cancers: sensitizers, clinical studies and future directives. Pharm. Res. 2000, 17, 1447-1455.

(4) Ochsner, M. Photophysical and photobiological processes in the photodynamic therapy of tumours. J. Photochem. Photobiol., B 1997, 39, $1-18$.

(5) Kennedy, J. C.; Marcus, S. L.; Pottier, R. H. Photodynamic therapy (PDT) and photodiagnosis (PD) using endogenous photosensitization induced by 5-aminolevulinic acid (ALA): mechanisms and clinical results. J. Clin. Laser Med. Surg. 1996, 14, 289-304.

(6) Peng, Q.; Warloe, T.; Berg, K.; Moan, J.; Kongshaug, M.; Giercksky, K. E.; Nesland, J. M. 5-Aminolevulinic acid-based photodynamic therapy. Clinical research and future challenges. Cancer 1997, 79, 2282-2308.

(7) Lopez, R. F. V.; Lange, N.; Guy, R.; Bentley, M. V. Photodynamic therapy of skin cancer: controlled drug delivery of 5-ALA and its esters. Adv. Drug Delivery Rev. 2004, 56, 77-94.

(8) Horn, M.; Wolf, P.; Wulf, H. C.; Warloe, T.; Fritsch, C.; Rhodes, L. E.; Kaufmann, R.; De Rie, M.; Legat, F. J.; Stender, I. M.; Soler, A. M.; Wennberg, A. M.; Wong, G. A. E.; Larko, O. Topical methyl aminolaevulinate photodynamic therapy in patients with basal cell carcinoma prone to complications and poor cosmetic outcome with conventional treatment. Br. J. Dermatol. 2003, 149, 1242-1249.

(9) Rhodes, L. E.; de Rie, M.; Enstrom, Y.; Groves, R.; Morken, T.; Goulden, V.; Wong, G. A.; Grob, J. J.; Varma, S.; Wolf, P. Photodynamic therapy using topical methyl aminolevulinate vs surgery for nodular basal cell carcinoma: Results of a multicenter randomized prospective trial. Arch. Dermatol. 2004, 140, 17-23.

(10) Yoon, J. H.; Yoon, H. E.; Kim, O.; Kim, S. K.; Ahn, S. G.; Kang, K. W. The enhanced anti-cancer effect of hexenyl ester of 5aminolaevulinic acid photodynamic therapy in adriamycin-resistant compared to non-resistant breast cancer cells. Lasers Surg. Med. 2012, $44,76-86$.

(11) Uehlinger, P.; Zellweger, M.; Wagnières, G.; Juillerat-Jeanneret, L.; van den Bergh, H.; Lange, N. 5-Aminolevulinic acid and its derivatives: physical chemical properties and protoporphyrin IX formation in cultured cells. J. Photochem. Photobiol., B 2000, 54, 72-80.

(12) Whitaker, C.; Battah, S.; Edwards, C.; Boyle, R.; Matthews, E. K. Photosensitization of pancreatic tumour cells by delta-aminolevulinic acids esters. Anti-Cancer Drug Des. 2000, 15, 161-170.

(13) Battah, S.; O’Neill, S.; Edwards, C.; Balaratnam, S.; Dobbin, P.; MacRobert, A. J. Enhanced porphyrin accumulation using dendritic derivatives of 5-aminolaevulinic acid for photodynamic therapy: An in vitro study. Int. J. Biochem. Cell Biol. 2006, 38, 1382-1392.

(14) Babič, A.; Herceg, V.; Ateb, I.; Allémann, E.; Lange, N. Tunable phosphatase-sensitive stable prodrugs of 5-aminolevulinic acid for tumor fluorescence photodetection. J. Controlled Release 2016, 235, $155-164$.

(15) Berkovitch, G.; Doron, D.; Nudelman, A.; Malik, Z.; Rephaeli, A. Novel multifunctional acyloxyalkyl ester prodrugs of 5-amino- 
levulinic acid display improved anticancer activity independent and dependent on photoactivation. J. Med. Chem. 2008, 51, 7356-7369.

(16) Bourre, L.; Giuntini, F.; Eggleston, I. M.; Wilson, M.; MacRobert, A. J. 5-Aminolaevulinic acid peptide prodrugs enhance photosensitization for photodynamic therapy. Mol. Cancer Ther. 2008, 7, 1720-1729.

(17) Giuntini, F.; Bourré, L.; MacRobert, A. J.; Wilson, M.; Eggleston, I. M. Improved peptide prodrugs of 5-ALA for PDT: rationalization of cellular accumulation and protoporphyrin IX production by direct determination of cellular prodrug uptake and prodrug metabolization. J. Med. Chem. 2009, 52, 4026-4037.

(18) Di Venosa, G.; Vallecorsa, P.; Giuntini, F.; Mamone, L.; Batlle, A.; Vanzuli, S.; Juarranz, A.; MacRobert, A. J.; Eggleston, I. M.; Casas, A. The use of dipeptide derivatives of 5-aminolaevulinic acid promotes their entry to tumor cells and improves tumor selectivity of photodynamic therapy. Mol. Cancer Ther. 2015, 14, 440-451.

(19) Konan, Y. N.; Gurny, R.; Allemann, E. State of the art in the delivery of photosensitizers for photodynamic therapy. J. Photochem. Photobiol., B 2002, 66, 89-106.

(20) Peng, Q.; Moan, J.; Warloe, T.; Iani, V.; Steen, H. B.; Bjorseth, A.; Nesland, J. M. Build-up of esterified aminolevulinic-acid-derivativeinduced porphyrin fluorescence in normal mouse skin. J. Photochem. Photobiol., B 1996, 34, 95-96.

(21) Peng, Q.; Berg, K.; Moan, J.; Kongshaug, M.; Nesland, J. M. 5Aminolevulinic acid-based photodynamic therapy: principles and experimental research. Photochem. Photobiol. 1997, 65, 235-251.

(22) Gardner, L. C.; Smith, S. J.; Cox, T. M. Biosynthesis of deltaaminolevulinic acid and the regulation of heme formation by immature erythroid cells in man. J. Biol. Chem. 1991, 266, 22010-22018.

(23) Hanania, J.; Malik, Z. The effect of EDTA and serum on endogenous porphyrin accumulation and photodynamic sensitization of human K562 leukemic cells. Cancer Lett. 1992, 65, 127-131.

(24) Liu, H. F.; Xu, S. Z.; Zhang, C. R. Influence of CaNa2 EDTA on topical 5-aminolaevulinic acid photodynamic therapy. Chin. Med. J. 2004, 117, 922-926.

(25) Barr, H.; Kendall, C.; Bazant-Hegemark, F.; Moayyedi, P.; Shetty, G.; Stone, N. Endoscopic screening and surveillance for Barrett's esophagus-clinical implications. MedGenMed 2006, 8, 88.

(26) Yang, J.; Xia, Y.; Liu, X.; Jiang, S.; Xiong, L. Desferrioxamine shows different potentials for enhancing 5-aminolaevulinic acid-based photodynamic therapy in several cutaneous cell lines. Lasers Med. Sci. 2010, 25, 251-257.

(27) Pourzand, C.; Reelfs, O.; Kvam, E.; Tyrrell, R. M. The iron regulatory protein can determine the effectiveness of 5-aminolevulinic acid in inducing protoporphyrin IX in human primary skin fibroblasts. J. Invest. Dermatol. 1999, 112, 419-425.

(28) Bech, O.; Phillips, D.; Moan, J.; MacRobert, A. J. A hydroxypyridinone (CP94) enhances protoporphyrin IX formation in 5-aminolaevulinic acid treated cells. J. Photochem. Photobiol., B 1997, 41, 136-144.

(29) Chang, S. C.; MacRobert, A. J.; Porter, J. B.; Brown, S. G. The efficacy of an iron chelator (CP94) in increasing cellular protoporphyrin IX following intravesical 5-aminolaevulinic acid administration: an in vivo study. J. Photochem. Photobiol., B 1997, 38, $114-122$.

(30) Curnow, A.; MacRobert, A. J.; Bown, S. G. Comparing and combining light dose fractionation and iron chelation to enhance experimental photodynamic therapy with aminolevulinic acid. Lasers Surg. Med. 2006, 38, 325-331.

(31) Curnow, A.; McIlroy, B. W.; Postle-Hacon, M. J.; Porter, J. B.; MacRobert, A. J.; Bown, S. G. Enhancement of 5-amino-laevulinic acid-induced photodynamic therapy in normal rat colon using hydroxypyridinone iron-chelating agents. Br. J. Cancer 1998, 78, $1278-1282$.

(32) Dobbin, P. S.; Hider, R. C.; Hall, A. D.; Taylor, P. D.; Sarpong, P.; Porter, J. B.; Xiao, G.; van der Helm, D. Synthesis, physicochemical properties, and biological evaluation of $\mathrm{N}$-substituted 2-alkyl-3hydroxy-4(1H)-pyridinones: orally active iron chelators with clinical potential. J. Med. Chem. 1993, 36, 2448-2458.
(33) Hershko, C.; Link, G.; Pinson, A.; Peter, H. H.; Dobbin, P.; Hider, R. C. Iron mobilization from myocardial cells by 3hydroxypyridin-4-one chelators: studies in rat heart cells in culture. Blood 1991, 77, 2049-2053.

(34) Porter, J. B.; Gyparaki, M.; Burke, L. C.; Huehns, E. R.; Sarpong, P.; Saez, V.; Hider, R. C. Iron mobilization from hepatocyte monolayer cultures by chelators: The importance of membrane permeability and the iron-binding constant. Blood 1988, 72, 1497-1503.

(35) Smith, A. G.; Clothier, B.; Francis, J. E.; Gibbs, A. H.; De Matteis, F.; Hider, R. C. Protoporphyria induced by the orally active iron chelator 1,2-diethyl-3-hydroxypyridin-4-one in C57BL/10ScSn mice. Blood 1997, 89, 1045-1051.

(36) Zhu, C. F.; Battah, S.; Kong, X. L.; Reeder, B. J.; Hider, R. C.; Zhou, T. Design, Synthesis and biological evaluation of 5-aminolaevulinic acid/3-hydroxypyridinone conjugates as potential photodynamic therapeutical Agents. Bioorg. Med. Chem. Lett. 2015, 25, 558561.

(37) Zhou, T.; Shao, L. L.; Battah, S.; Zhu, C. F.; Hider, R. C.; Reeder, B. J.; Jabeen, A.; MacRobert, A. J.; Ren, G. R.; Liang, X. L. Design and synthesis of 5-aminolaevulinic Acid/3-hydroxypyridinone conjugates for photodynamic therapy: enhancement of protoporphyrin IX production and photo-toxicity in tumor cells. MedChemComm 2016, 7, 1190-1196.

(38) Hoyes, K. P.; Porter, J. B. Subcellular-distribution of desferrioxamine and hydroxypyridin-4-one chelators in K562 cells affects chelation of intracellular iron pools. Br. J. Haematol. 1993, 85, 393-400.

(39) Xie, Y. Y.; Liu, M. S.; Hu, P. P.; Kong, X. L.; Qiu, D. H.; Xu, J. L.; Hider, R. C.; Zhou, T. Synthesis, physico-chemical properties, an antimicrobial evaluation of a new series of iron(III) hexadentate chelators. Med. Chem. Res. 2013, 22, 2351-2359.

(40) Feuerstein, T.; Berkovitch-Luria, G.; Nudelman, A.; Rephaeli, A.; Malik, Z. Modulating ALA-PDT efficacy of mutlidrug resistant MCF-7 breast cancer cells using ALA prodrug. Photochem. Photobiol. Sci. 2011, 10, 1926-1933.

(41) Wu, R. W.; Chu, E. S.; Yow, C. M.; Chen, J. Y. Photodynamic effects on nasopharyngeal carcinoma (NPC) cells with 5-aminolevulinic acid or its hexyl ester. Cancer Lett. 2006, 242, 112-119.

(42) Jerjes, W.; Upile, T.; Hamdoon, Z.; Mosse, C. A.; Akram, S.; Hopper, C. Photodynamic therapy outcome for oral dysplasia. Lasers Surg. Med. 2011, 43, 192-199.

(43) Dogra, Y.; Ferguson, D. C. J.; Dodd, N. J. F.; Smerdon, G. R.; Curnow, A.; Winyard, P. G. The hydroxypyridinone iron chelator CP94 increases methyl-aminolevulinate-based photodynamic cell killing by increasing the generation of reactive oxygen species. Redox Biol. 2016, 9, 90-99.

(44) De Rosa, F. S.; Tedesco, A. C.; Lopez, R. F. V.; Riemma Pierre, M. B.; Lange, M.; Marchetti, J. M.; Gomes Rotta, J. C. G.; Lopes Badra Bentley, M. V. In vitro skin permeation and retention of 5aminolevulinic acid ester derivatives for photodynamic therapy. $J$. Controlled Release 2003, 89, 261-269.

(45) Rodriguez, L.; Batlle, A.; Di Venosa, G.; Battah, S.; Dobbin, P.; MacRobert, A. J.; Casas, A. Mechanisms of 5-aminolevulinic acid ester uptake in mammalian cells. Br. J. Pharmacol. 2006, 147, 825-833.

(46) Curnow, A.; Pye, A. The importance of iron chelation and iron availability during PpIX-induced photodynamic therapy. Photonics Lasers Med. 2015, 4, 39-58.

(47) Di Venosa, G. M.; Casas, A. G.; Battah, S.; Dobbin, P.; Fukuda, H.; MacRobert, A. J.; Batlle, A. Investigation of a novel dendritic derivative of 5-aminolaevulinic acid for photodynamic therapy. Int. J. Biochem. Cell Biol. 2006, 38, 82-91.

(48) Giuntini, F.; Bourré, L.; MacRobert, A. J.; Wilson, M.; Eggleston, I. M. Quantitative determination of 5- aminolaevulinic acid and its esters in cell lysates by HPLC-fluorescence. J. Chromatogr. B: Anal. Technol. Biomed. Life Sci. 2008, 875, 562-566.

(49) Dixon, M. B.; Bourré, L.; MacRobert, A. J.; Eggleston, I. M. Novel prodrug approach to photodynamic therapy: Fmoc solid-phase synthesis of a cell permeable peptide incorporating 5-aminolaevulinic acid. Bioorg. Med. Chem. Lett. 2007, 17, 4518-4522. 